WHITE PAPER ON EDUCATION AND TRAINING

\title{
TEACHING AND LEARNING
}

$$
\star * *
$$

\section{TOWARDS THE LEARNING SOCIETY}


"We must have the courage to examine everything, discuss everything and even to teach everything"

Condorcet

\section{FOREWORD}

This White Paper is part of a process designed simultaneously to provide an analysis and to put forward guidelines for action in the fields of education and training. It takes forward the White Paper "Growth, competitiveness, employment", which stressed the importance for Europe of intangible investment, particularly in education and research. This investment in knowledge plays an essential role in employment, competitiveness and social cohesion. This White Paper whilst looking forward to the Madrid European Council meeting, draws upon the conclusions of the Cannes European Council of June 1995, which state that: "Training and apprenticeship policies, which are fundamental for improving employment and competitiveness, must be strengthened, especially continuing training".

Articles 126 and 127 of the Treaty establishing the European Community stipulate respectively that "the Community shall contribute to the development of quality education by encouraging cooperation between Member States and, if necessary, by supporting and supplementing their action" and that "the Community shall implement a vocational training policy which shall support and supplement the action of the Member States".

These articles are the clear basis for the debate which the Commission, in presenting this White Paper, intends to launch in 1996, the year which the Council and the European Parliament have chosen as the European Year of Lifelong Learning.

After describing what is at stake and analysing the changes which need to be considered, while respecting the principle of subsidiarity, the White Paper sets out the action to be taken in the Member States and the support measures to be introduced at Community level. The main lines of action at the European level envisaged for 1996 include objectives to:

- $\quad$ encourage the acquisition of new knowledge;

- $\quad$ bring school and the business sector closer together;

- $\quad$ combat exclusion;

- develop proficiency in three European languages;

treat capital investment and investment in training on an equal basis. 


\section{CONTENTS}

INTRODUCTION

PART ONE: THE CHALLENGES

I. THE THREE FACTORS OF UPHEAVAL 5

A. The impact of the information society 6

$\begin{array}{ll}B . & \text { The impact of internationalisation } \\ \end{array}$

$\begin{array}{lll}\text { C. } & \text { The impact of scientific and technological knowledge } & 7\end{array}$

II. A FIRST APPROACH:

FOCUSING ON A BROAD KNOWLEDGE BASE 9

A. Grasping the meaning of things $\quad 10$

B. Comprehension and creativity 11

C. Powers of judgement and decision making 11

III. A SECOND RESPONSE:

DEVELOPING EVERYONE'S EMPLOYABILITY

AND CAPACITY FOR ECONOMIC LIFE 12

A. What are the skills required? $\quad 12$

B. How can a person become employable ? 14

IV. DIRECTIONS FOR THE FUTURE 22

A. The end of debate on educational principles 22

$B$. The central question: towards greater flexibility 23

C. Action in the Member States 23

D. New developments 25 
PART TWO: BUILDING THE LEARNING SOCIETY

I. FIRST GENERAL OBJECTIVE :

"ENCOURAGE THE ACQUISITION OF NEW KNOWLEDGE" 32

A. Recognition of skills 32

B. Mobility 33

C. Multimedia educational software 33

II. SECOND GENERAL OBJECTIVE :

"BRING SCHOOLS AND BUSINESS CLOSER TOGETHER" 36

A. Apprenticeship/Trainees schemes 37

B. Vocational training 38

III. THIRD GENERAL OBJECTIVE : "COMBAT EXCLUSION"

A. Second chance schools 40

B. European voluntary service 42

IV. FOURTH GENERAL OBJECTIVE :

"PROFICIENCY IN THREE COMMUNITY LANGUAGES"

V. FIFTH GENERAL OBJECTIVE :

"TREAT CAPITAL INVESTMENT AND INVESTMENT IN TRAINING ON A EQUAL BASIS"

GENERAL CONCLUSION

Annex 1 : Some data and figures

Annex 2 : Examples of Community programmes in the field of education and training

Annex 3 : The educational world of Alyat Hanoar 60

Annex 4 : The experience of "Accelerated schools" in the USA

62 


\section{INTRODUCTION}

Much of the effort made in recent years to stem the rise of unemployment in Europe has not had lasting effects. Jobs created in the wake of a return to periods of higher growth have not reversed the long term trends. Long term unemployment continues to increase and the spread of social exclusion, particularly among young people, has become a major problem in our societies.

Education and training have now emerged as the latest means for tackling the employment problem. It may be surprising that the realisation of the role they can play has come so late and that it has taken an economic recession to bring it about. Yet it is unfair to expect education and training alone to make up for every failure: education and training cannot solve the employment problem on their own or, more generally, the problem of the competitiveness of industries and services. Moreover, while it is true that the Treaty on European Union has opened up scope for Community action in these areas, it also states explicitly that the role at European level is to support and supplement action taken by the Member States.

Be that as it may, the countries of Europe today have no other option. If they are to hold their own and continue to be a reference point in the world, they have to build on the progress brought about through closer economic ties by more substantial investment in knowledge and skills.

The Commission established the general framework for its analysis in its White Paper "Growth, competitiveness and employment", drawn up on the initiative of Jacques Delors, which stressed that the development of education and training is one of the conditions for the development of a new model of more employmentintensive growth.

The Essen European Council of December 1994 confirmed this in its conclusions and re-affirmed them in Cannes in June 1995, in the light of the report from the Advisory Group on Competitiveness.

There are two major challenges: firstly, providing immediate solutions to current education and training needs; secondly, preparing the future and outlining an overall approach capable of assembling the efforts of the Member States and those of the European Union, each acting within its area of competence.

Since the 1960's, Community action in education and training has had significant results in terms of cooperation, exchanges of experience, supporting innovation and the development of training products and materials. It has also boosted decisively European mobility of students and people in training. It has also contributed to the promotion of learning Community languages and to the development of communication between European citizens (see annex 2).

The basis of this White Paper is the concerns of every European citizen, young or adult, who faces the problem of adjusting to new conditions of finding a job and 
changes in the nature of work. No social category, no profession, no trade is spared this problem.

The internationalisation of trade, the global context of technology and, above all, the arrival of the information society, have boosted the possibilities of access to information and knowledge for people, but at the same time have as a consequence changed work organization and the skills learned. This trend has increased uncertainty for all and for some has led to intolerable situations of exclusion.

It is clear that the new opportunities offered to people require an effort from each one to adapt, particularly in assembling one's own qualifications on the basis of 'building blocks' of knowledge acquired at different times and in various situations.

The society of the future will therefore be a learning society. In the light of this it is evident that education systems - which means primarily the teachers - and all of those involved in training have a central role to play. The social partners, in exercising their responsibilities, including through collective bargaining, have a particularly important role, as these developments will condition the working environment of the future.

Education and training will increasingly become the main vehicles for selfawareness, belonging, advancement and self-fulfilment. Education and training whether acquired in the formal education system, on the job or in a more informal way, is the key for everyone to controlling their future and their personal development.

Education and training remain one of the determining factors in equality of opportunity. Education systems have already played an essential role in the emancipation and the social and professional advancement of women. Education can and must contribute further to the crucial equality between men and women.

Immaterial investment and getting the best out of our human resources will improve competitiveness, boost jobs and safeguard social achievements. The individual's place in relation to their fellow citizens will increasingly be determined by their capacity to learn and master fundamental knowledge.

The position of everyone in relation to their fellow citizens in the context of knowledge and skills therefore will be decisive. This relative position which could be called the "learning relationship" will become an increasingly dominant feature in the structure of our societies.

The ability to renew and innovate will depend on the links between the development of knowledge in research and its transmission through education and training. In all this, communication will be essential both for generating and disseminating ideas.

The future of the EU and its development will depend largely on its ability to manage the progress towards this new society. The objective is to make it into a just and progressive society based on its cultural wealth and diversity. There is a 
need to whet society's appetite for education and training throughout life. There needs to be permanent and broad access to a number of different forms of knowledge. In addition, the level of skill achieved by each and everyone will have to be converted into an instrument for measuring individual performance in a way which will safeguard equal rights for workers as far as possible.

There is no single pattern for all to follow throughout their working lives. Everyone must be able to seize their opportunities for improvement in society and for personal fulfilment, irrespective of their social origin and educational background. This particularly applies to the most disadvantaged groups who lack the family and social environment to enable them to make the most of the general education provided by school. These groups should be given the chance not just to catch up, but to gain access to new knowledge which could help to bring out their abilities.

Given the diversity of national situations and the inadequacy of global solutions in this context, proposing a model is not the answer. This would be doomed to failure given the pivotal role of the individual in the construction of the learning society and the social and cultural diversity of the Member States. The purpose of this White Paper is to plot out the route to this new society by identifying the options available to the EU in education and training. Its suggestions, guidelines and aims are intended to support and supplement education and training policies, the responsibility for which rests first and foremost with national, regional and local authorities. The objective is not to impose common rules, but rather on the basis of a broad debate to identify the points of convergence and the actions capable of meeting the current challenges.

The diversity of the education systems of the EU notwithstanding, there is a European approach to education based on common historic roots, from which stems the success of cooperation between higher education establishments, for example, in the ERASMUS programme which has provided mobility for 500,000 young students.

In the new context of the internationalisation of the economy, dissemination of new technologies and the risk of cultural uniformity, Europe more than ever before is an appropriate level for action. This will in the future be amply borne out by the impact of the free movement of people, which will make it essential for national education and training systems to consider the European dimension.

To examine education and training in the context of employment does not mean reducing them simply to a means of obtaining qualifications. The essential aim of education and training has always been personal development and the successful integration of Europeans into society through the sharing of common values, the passing on of cultural heritage and the teaching of self-reliance.

However, this essential function of social integration is today under threat unless it is accompanied by the prospect of employment. The devastating personal and social effects of unemployment are uppermost in the minds of every family, every 
young person in initial training and everyone on the labour market. The best way for education to continue to exercise this essential function is to seek to provide a convincing response to alleviate these concerns. The very foundations of any European society purporting to teach its children the principles of citizenship would be undermined if this teaching were to fail to provide for job prospects.

In the face of unemployment and technological upheaval, training must go beyond the framework of initial education and develop an on-going capacity for the renewal of the technical and vocational skills of workers around a solid, broad knowledge base.

This White Paper takes the view that in modern Europe the three essential requirements of social integration, the enhancement of employability and personal fulfilment, are not incompatible. They should not be brought into conflict, but should on the contrary be closely linked. Europe's assets in the area of science, the depth of its culture, the capacity of its business, industry and institutions should enable it both to pass on its fundamental values and prepare for employment. This presupposes that European society stays tuned to the underlying trends at work within it.

On this basis, the White Paper considers in turn:

- $\quad$ the importance of education and training to Europe in the current context of technological and economic change; and

- $\quad$ the guidelines for action in the pursuit of objectives to build up high-quality education and training. 


\section{PART ONE: THE CHALLENGES}

As this century draws to its close, we can see that the causes of change in society have been diverse and have affected our education and training systems in different ways. Demographic trends have increased life expectancy radically changing at the same time the age structure of the population, thereby increasing the need for lifelong learning. The substantial rise in the number of working women has altered the traditional place of the family in relation to school and the upbringing of children. Expansion of technical innovation in all areas has generated new knowledge requirements. Consumption patterns and lifestyles have changed. In addition, people have been alerted to environmental problems and the use of natural resources and this has affected both education and training systems and industrial activities.

Three major, profound and wideranging factors of upheaval have emerged, however, which have transformed the context of economic activity and the way our societies function in a radical and lasting manner, namely: the onset of the information society; the impact of the scientific and technological world; and the internationalisation of the economy. These events are contributing towards the development of the learning society. They bring risks, but also opportunities which must be seized.

The construction of this society will depend on the ability to respond in two important ways to the implications of these events. The first response focuses on the need for a broad knowledge base and the second is designed to build up abilities for employment and economic life.

Establishing the learning society will also depend on how those involved and the institutions in education and training pursue the developments already under way in the Member States.

\section{The three factors of upheaval}

Like the rest of the world, Europe has to face up to the effects of the widespread dissemination of information technologies, pressure on the world market and a relentless onward march of science and technology. These challenges represent a step forward by placing people in a closer relationship with another.

Europe has been confronted by global technological and economic developments in a context of unemployment levels higher than in other parts of the world and an increase in social exclusion. This has led some to consider technology as an intrinsic and definitive obstacle to employment growth, while others believe that the level of social protection in those countries hardest hit has generated fixed costs which need to be seriously reconsidered. It has forced others back into a nationalistic shell which can be interpreted as an inability to devise and build a new model of society.

This White Paper considers that European society is in a transitional phase towards a new 
form of society beyond current short term forecasts.

\section{A. The impact of the information society}

The report "Europe and the global information society" (May 1994), produced by the high-level group chaired by Mr Bangemann, stressed, "that throughout the world, information and telecommunications technologies are bringing about a new industrial revolution which already looks to be as important and radical as those which preceded it".

This revolution like previous ones will have consequences for work and employment.

It has not been demonstrated that new technologies reduce employment levels. Some technologically advanced countries have created around the new information related activities, a number of jobs comparable, indeed in some cases higher, than those lost in other areas.

It is however certain that information technologies have radically changed the nature of work and the organisation of production. These changes are currently affecting deeply European society.

Mass production is declining and making room for a more customized type of production. The traditional pattern of growth in paid employment, i.e. full time and permanent, appears to be on the decline. Production relationships and conditions of employment are changing. Corporate organisation is increasingly turning towards flexibility and decentralisation. The search for flexibility, the development of networked-based cooperation, the increased use of subcontracting, the development of work in teams, are some of the consequences of information technology.

Information technology is contributing to the disappearance of routine and repetitive work which can be codified, programmed and automated. Work content will increasingly be made up of intelligent tasks requiring initiative and the ability to adapt.

Although it makes the decentralisation of tasks easier, information technology coordinates these tasks in interactive on-line communication networks which function equally well across continents as from one office and floor to another. The result is simultaneously a higher level of individual autonomy for workers, but a less clear perception of the context of their actions. The new technologies have a twofold effect. On the one hand, they considerably increase the role of the human factor in the production process, while on the other make workers more vulnerable to changes in work organisation because they are mere individuals within a complex network.

Information technologies are making significant inroads into productionrelated activities and into education and training, thus bringing the 'learning system' and the 'producing system' closer together. There is a marked convergence between the world of work and the world of learning/training as far as the capacities required are concerned. 
Change connected with information technology has wide economic and social consequences for the development of: self-employment; service industries; new forms of work organisation known as the "learning organisation"; management decentralisation; and flexible working hours.

The information society, notwithstanding the new knowledge techniques it heralds, raises the question of whether the educational content it carries will enhance or, on the contrary, diminish the knowledge of the individual. The focus up to now has been on the potential offered by information highways, through the revolutionary quasiinstantaneousness that the INTERNET, for instance, brings to contacts between firms, researchers and academics. The fear is the risk that the quality of multi-media products, particularly in educational software, could lead to knowledge of the "lowest common denominator" in which people lose their historical, geographical and cultural bearings.

This is why the Commission, particularly at the G7 meeting on the information society in Brussels in February 1995, stressed the need to stimulate European production of educational software. The information society is going to change teaching methods by replacing the excessively passive teacher/pupil relationship with a new - and seemingly promising - interactive relationship. At the same time, however, changing teaching methods does not affect the content of the material taught.

\section{B. The impact of internationalisation}

The internationalisation of the economy is the second factor of upheaval, which has given rise to unprecedented freedom of movement for capital, goods and services.

Sooner than is generally believed, a global and distinctive labour market will emerge. Large and small companies, and even the mobile professions, are already using "teleporting" to have work done online in low-wage countries.

In its White Paper "Growth, competitiveness and employment" the Commission opted clearly for a Europe open to the rest of the world but stressed that its future developments should have a distinct European dimension, placing particular emphasis on the preservation of the European social model. Internationalisation thus simply strengthens Europe's position on the world stage. In a changing and uncertain world, Europe is a natural level of organisation. This has been shown through trade policy, technical harmonisation, environmental protection, solidarity between the regions and through real progress in the field of education and training, e.g. in the ERASMUS programme. Yet, Europe still needs to demonstrate to ordinary people that it is not there just to make regulations, but that it is close to their everyday concerns.

This option, involves improving the competitiveness of our economies, and will increase the quality of life 
through more efficient distribution of resources in the world. It nevertheless implies major adjustments in every country.

There is a risk of a social rift with all the adverse and even drastic consequences this may entail.

\section{The impact of scientific and technological knowledge}

The developments and dissemination of scientific and technical knowledge is accelerating.

A new model of production of knowledge and know-how is emerging, combining extreme specialisation and cross-disciplinary creativeness. Industry relies increasingly on science to develop new products (e.g. special alloys for sports equipment, biological processes for environmental industries) and scientific research needs equipment with a high degree of technical sophistication (e.g. supercomputers, high-performance communications networks, human genomes).

But instead of celebrating progress as was the case a century ago, public opinion often perceives scientific ventures and technological progress as a threat.

These growing anxieties are a significant feature of the end of this century. Paradoxically, whereas science is making significant progress (limiting, if not overcoming famine and many diseases, increasing life expectancy, providing faster communication etc.), this progress is for many people matched by a sense of fear which has some parallels in the transition from the Middle Ages to the Renaissance.

Media coverage also presents a violent picture, re-enforcing these anxieties.

To tackle this crisis better information is essential but insufficient on its own. It is by disseminating knowledge that this irrational climate can be overcome. By demonstrating the link between science and the progress of mankind, while being fully aware of its limitations, today's scientific and technological world will be accepted and in a better position to spread widely an innovative culture.

In many European countries, the response is pitched at two levels, cultural and ethical.

The promotion of a scientific and technical culture is the subject of a sustained effort by the public authorities.

Activities at national level on this issue have, since 1993, been enhanced and complemented by a timely European event, the "European week of scientific culture", the success of which is growing in all the countries of the European Union. But it is at school that the issue is really determined. Scientific and technical information is all the more rewarding when built on a solid foundation of scientific education acquired at school.

The second level is ethical. The development of biotechnologies, man's relationship to intelligent machines, new approaches to 
procreation, a heightened sense of co-existence with other species, protection of the environment, are all new issues which Europe must prepare to face. The same problem arises in relation to the information society. The 'information highways' to which young people and even children will have increasingly easier access, could well find themselves inundated with messages offending human dignity. This clearly raises the matter of protecting our children. The ethics of responsibility must become an integral part of basic education and the training of researchers.

Throughout Europe, in all Member States, these three factors of upheaval and their repercussions for industry and employment are increasingly being taken on board and addressed. For example, see the report of the German Federal Government on "The future of Germany as an industrial location" (Bundesministerium für Wirtschaft, September 1993). At European level, the White Paper on "Growth, Competitiveness and Employment" and the conclusions of the Essen European Council, reiterated in Cannes, stress the link between competitiveness, employment, education and training.

The response to these three factors of upheaval is multi-faceted, for it entails a radical shake-up of European society.

The ultimate goal of training, to build up the individual's self-reliance and occupational capacity, makes it the linchpin of adaptation and change. The two main responses focused upon in this White Paper are accordingly to give everyone access to a broad base of knowledge and to build up their abilities for employment and economic life.

\section{A first approach: focusing on a broad knowledge base}

In the future, individuals will be called upon to understand complex situations which will change in unforeseeable ways, but which advances in science should nevertheless make it easier to control. They will also be confronted with an increasing variety of physical objects, social situations and geographical and cultural contexts. In addition, they will have to contend with a mass of fragmentary and incomplete information open to varying interpretations and partial analysis.

There is therefore a risk of a rift in society between those that can interpret; those who can only use; and those who are pushed out of mainstream society and rely upon social support: in other words, between those who know and those who do not know.

The main challenge in this kind of society is to reduce the gap between these groups whilst enabling the progress and development of all human resources.

It is possible to understand the world if the way it interacts and functions can be grasped and a sense of personal direction found. This is the main function of school. This is particularly appropriate to the building 
of Europe. By imparting a broad knowledge base to young people enabling them both to pick their way through its complexity and to discuss its purpose, education lays the foundations of awareness and of European citizenship.

By the same token, the development of a broad knowledge base, namely the ability to grasp the meaning of things, to comprehend and to make judgements, is the first factor in adapting to economic and labour market change. The report from the Round Table of European Industrialists (February 1995) stressed the need for flexible training with a broad knowledge base, advocating a 'learning to learn' approach throughout life. It stated that, "the essential mission of education is to help everyone to develop their own potential and become a complete human being, as opposed to a tool at the service of the economy; the acquisition of knowledge and skills should go hand in hand with building up character, broadening outlook and accepting one's responsibility in society.".

This need for a solid and broad knowledge base which is literary, philosophical, scientific, technical and practical, does not only concern initial training. There are many examples to show that the vocational retraining of employees who are under skilled or highly specialised on account of the Taylorist approach to work depends upon the acquisition of this base as the foundation for new technical skills. When retraining workers, training establishments are increasingly having to give them a general grounding before teaching them a new job.
There is, moreover, an increasing degree of convergence between business and the world of education when it comes to the usefulness of reconciling general education and specialised training.

More generally speaking, the forceful return of a broad knowledge base as the key to understanding the world outside the context of education can be seen.

\section{A. Grasping the meaning of things}

In an essentially universal society based on knowledge, a social and cultural identity can only be passed on in part. It has to be built up, not only by school the role of which continues to be irreplaceable, but the individuals who draw on the collective memory while assimilating the variety of information to which they are exposed, through their involvement in different, vocational, cultural, social and family circles.

The future of European culture depends on its capacity to equip young people to question constantly and seek new answers without prejudicing human values. This is the very foundation of citizenship and is essential if European society is to be open, multicultural and democratic.

In this regard, the most eminent academics stress the importance of adequate scientific awareness - not simply in the mathematical sense - to ensure that democracy can function properly. Democracy functions by majority decision on major issues which, because of their complexity, require an increasing amount of background knowledge. 
For example, environmental and ethical issues cannot be the subject of informed debate unless young people possess a certain scientific awareness. At the moment, decisions in this area are all too often based on subjective and emotional criteria, the majority lacking the general knowledge to make an informed choice. Clearly this does not mean turning everyone into a scientific expert, but enabling them to fulfil an enlightened role in making choices which affect their environment and to understand in broad terms the social implications of debates between experts. There is similarly a need to make everyone capable of making considered decisions as consumers.

The radical changes taking place in the scientific and technological landscape, require individuals (even if they do not aspire to a career in research) increasingly to be able to grasp the meaning of things. Individuals must also learn to think more in terms of systems and to position themselves both as a user and as a citizen, as an individual and as a member of a group.

Literature and philosophy fulfil the same function in respect to the indiscriminate bombardment of information from the mass media and, in the near future, from the large informatics networks. They arm the individual with powers of discernment and a critical sense. This can provide the best protection against manipulation, enabling people to interpret and understand the information they receive.

It is nevertheless worth stressing the educational role the mass media can fulfil. Wide-audience TV channels, e.g. the BBC in the United Kingdom, or more specialised channels e.g. La Cinquième in France, offer educational programmes, providing viewers with a substantial range of learning material.

In conjunction with the public authorities, the mass media makes it possible to reach attainment targets which could not be achieved by traditional means. A very successful example of this is the BBC's recent "Read and write" campaign targeted at disadvantaged groups, parents and children alike and designed to help stamp out illiteracy.

A broad knowledge base enables people to find their way in the information society, that is to say to be able to interpret in a critical way the images and information they receive from a variety of sources.

\section{B. Comprehension creativity}

and

The ability to understand is the capacity to analyze how things are assembled and taken apart. One function of this White Paper is to draw attention to the crucial matter of teaching to promote innovation.

In fact an excessive standardisation of knowledge prevails. It tends to give the impression that everything has to be taught in a strictly logical order and that producing and identifying quality is a question of mastering a deductive reasoning system based on abstract concepts, in which mathematics play a predominant role. In certain cases deductive approaches can thus make students passive and restrict the imagination.

Observation, common sense, curiosity, interest in the physical and 
social world around us and the desire to experiment are qualities which are often neglected. Yet these are the qualities which will enable us to train inventors rather than mere technology managers.

In yesterday's Europe, irrespective of whether it was rooted in rural life or in manufacturing industry, learning was naturally directed primarily at the acquisition of abstract concepts to round off practical skills absorbed from day-to-day life outside school. The greater part of this practical knowledge base has been modified and has regressed in our urbanised, automated, media-dominated society. It needs to be brought back into a broader knowledge base as a way of preparing individuals to master the technical instruments they will have to use, so that they, rather than the technique, are in charge.

Developing these aptitudes means promoting an appreciation of how society has been enriched by invention and how such invention came about. Any action taken by the Member States to introduce the history of science and technology into schools and to strengthen the links between research and basic education should be encouraged.

\section{Powers of judgement and decision making}

Powers of judgement and the ability to choose are the two essential skills for understanding the world around us. They involve: criteria for making choices; remembering the lessons of the past; and an ability to assess the future.

The ability to choose is based on personal and social values, as well as being able to rationalize the world in which we live.

Recalling and understanding the past is essential in order to judge the present. Knowledge of history (including scientific and technological history) and geography has a dual function as a guide in time and space which is essential to everyone if they are to come to terms with their roots, develop a sense of belonging and to understand others. It is small wonder that the hallmark of authoritarian regimes and dictatorships has been the undermining and falsifying of the teaching of history. The penalty society pays for forgetting the past is to lose a common heritage of bearings and reference points. It is not surprising that, not knowing the history of European civilisation, that such expressions as, "being out in the wilderness", "having a cross to bear", "Eureka!", "the judgment of Solomon" or "the tower of Babel" have lost their meaning.

In the end, it is by presenting the world not as a completed construction, but as something to be constructed, that an instinct for the future will be cultivated.

School must not only allow for critical faculties to be developed at all levels, among both pupils and teachers, it must also encourage it. Its open environment, cooperation requirements and duty to prepare young people for employment must not be allowed to prevent it from accomplishing its main function, however, which is to guide the young people in its care in their personal and social development. This White Paper contends that in tomorrow's society these two demands will be 
even more compatible than at present.

\section{A second response: developing everyone's employability and capacity for economic life}

One of the central issues this White Paper seeks to answer, is how best to use education and training to commit European countries to a process of job creation, whilst taking control of the internationalization of the economy and the arrival of new technologies

Two questions follow: what are the skills required and how can they be acquired?

\section{A. What are the skills required?}

In today's world, knowledge in the broad sense can be defined as an acquired body of fundamental and technical knowledge, allied to social skills. It is the balance of this knowledge acquired through the formal education system, in the family, on the job and through various information networks, which make it the broad and transferable body of knowledge which is most favourable to employment.

Basic knowledge is the foundation on which individual employability is built. This is par excellence the domain of the formal education and training system. A good balance has to be struck in basic education between acquiring knowledge and methodological skills which enable a person to learn alone. It is these which today need to be developed.
Over the past few years, European countries have opted to re-centre basic teaching on the "three Rs" reading, writing and arithmetic - in order to prevent school failure which plays a major role in social exclusion.

An early start in education i.e. at the pre-school age is also becoming more common. Pupils who receive pre-school education are seen to succeed on average better during their school careers than others. They take their studies further and seem to integrate more easily.

Language learning also needs to be encouraged. A project entitled Euroling is being carried out in this context under the SOCRATES programme and has produced teaching material in three languages (Italian, Spanish, Dutch) for nursery and primary schools. Early teaching of language, starting at nursery school, should become part of basic knowledge. The European Commission believes that it is necessary to make proficiency in at least two foreign languages at school a priority, as is proposed in the second part of this White Paper.

Technical knowledge is knowledge which permits clear identification with an occupation. It is acquired partly within the vocational education and training system and partly on the job. This knowledge has substantially changed with the advent of information technology and the demarcation lines between occupations are breaking down. Within this framework of knowledge, certain "key skills" are central to a number of different occupations and therefore essential in order to be able to change jobs. Basic training in 
information technology across the board has therefore become a necessity.

However, acquiring technical knowledge should not be restricted to leading-edge or newly-emerged sectors. There are long-established, but still efficient sectors of industry, with a genuine tradition of competence totally in keeping with the notion of work-shadowing and mentoring. This tradition is still a valid source of inspiration and produces workers who have mastered all the different facets of their craft and who are able to pass them on to others.

Social aptitudes concern interpersonal skills, i.e. behaviour at work and a whole range of skills corresponding to the level of responsibility held, such as the ability to cooperate and work as part of a team, creativeness and the quest for quality. Full mastery of these skills can be acquired only in a working environment and therefore mainly on the job.

The employability of a person and their capacity to adapt are linked to the way they are able to combine these different types of knowledge and build on them. In this context, individuals become the principal constructor of their own abilities and can combine the skills acquired through the traditional institutional routes, with those acquired through their occupational experience and those acquired by virtue of their personal training effort.

By diversifying education provision, building bridges between various channels, increasing preoccupational experience and by opening up the potential for mobility as widely as possible, people can build up and build on their level of employability and better control their career.

\section{B. How can a person become employable?}

\section{The traditional route: the paper qualification}

People today opt for general education or vocational training routes leading to paper qualifications, remaining as long as possible within the education system.

There is indeed a trend in all the Member States to lengthen the period of study and strong social pressure to broaden access to higher education and thus raise the level achieved by the greatest number. This also concerns young people who have opted for vocational courses and even those who have had work experience. This situation raises problems for the attractiveness of vocational education, which in several Member States is considered as a 'second best' option offering limited career prospects. Young people therefore tend to go for general education at the risk of feeling overqualified in their jobs.

This type of behaviour by young people is rational because level of study and the paper qualification still provide far and away the best passport to employment. However, from the social point of view this raises problems. Young people who have lower levels of qualification are forced into lower-qualified jobs than those to which they hoped to aspire. This "domino effect" also affects those with few or no paper 
qualifications and becomes a major factor of social exclusion. Overqualification for jobs also hinders career progress.

In most European systems, paper qualifications are designed with a view to filtering out at the top the elite which will lead administration and companies, researchers and teaching staff. In certain countries, they are even the quasi-absolute reference points for assessing competence, which makes it a powerful incentive to pursue longterm studies and to take one's chance in very selective courses. Moreover, a worker's occupational status is in many countries defined by the diploma held. This link between paper qualification and status, however logical it may be, accentuates the internal lack of flexibility of the labour market.

It could be considered that society "locks out" in this way much talent which is frequently unconventional but innovatory and that it therefore produces an elite which is not truly representative of the available human resource potential. This point of view is borne out by a number of recent surveys which show that over a long period the more elitist types of training are more often than not the prerogative of the upper managerial or intellectual strata.

This is not, of course, to say that the paper qualification is not a valid route. The substantial efforts made by the Member States, and supported by the Community through SOCRATES and LEONARDO to strengthen initial training must of course be pursued. But in parallel with this, we need to make the best use of skills and abilities irrespective of how they were obtained and to enhance everyone's potential by catering more closely for the needs of the individual, business and industry. What is needed is a more open and flexible approach. Such an approach should also encourage lifelong learning by allowing for and encouraging a continuing process of skill acquisition.

\section{The modern route: integration within a network which cooperates, which educates, trains and learns}

If people are to exercise their responsibilities to a greater extent in shaping their skills and abilities they must first be able to enter institutional training systems more easily. This implies familiarity with them, broader access and better mobility between the different courses.

There are two possible answers. Either the level of paper qualifications is maintained, in which case the number of young people having no paper qualifications increases, or else the number of paper qualifications or the number of young people holding such qualifications has to be increased, thus inevitably placing question marks around the quality of those qualifications.

These are questions which recur in all Member States, as does the question of the high number of young people leaving education without qualifications and with a feeling of personal failure, who are consequently vulnerable on the employment market through the total lack of any recognised skills.

This White Paper suggests a third way forward, which already exists in some Member States. This 
solution does not detract from the paper qualification, but on the contrary helps to maintain its quality and is to recognise partial skills on the basis of a reliable accreditation system. Those rejected by the formal system of education would be encouraged to cultivate the skills they have. This does not mean qualifications in the broad sense but skills based on specific fundamental or vocational know-how (knowledge of a language, a given level in maths, accounting, using a spreadsheet, word processing, etc.). These partial skills could also be possessed by adults who have some expertise due to their own self-teaching efforts (e.g. computer skills) and who could be encouraged to hone these skills. Accreditation of this kind could, of course, lead to the recognition on a broader basis of the technical knowledge acquired in a firm, which is currently more often than not evaluated solely for the company's use.

However, whether the knowledge and skills are acquired within a formal system of education or in a less formal way, the individual still needs to be assisted. The most efficient education and training approaches are those which operate within a network. These networks may be institutional (education and training establishments cooperating with families or firms) or informal networks of knowledge which are rapidly springing up (adult education establishments, education cooperatives, etc.).

\section{a) Promoting access to education and training}

Once the basics have been secured, two conditions would appear to be necessary if individuals are to be able to exercise responsibility in building up their abilities:

adequate information and
guidance;

- $\quad$ access to training along with all the opportunities available for mobility.

i) $\frac{\text { Information and guidance }}{\text { constitute the first condition. }}$

For a young person seeking to find their way, for an adult undergoing vocational or continuing training, there is the problem of an abundance of provision and its presentation. The citizen of Europe has better information when choosing a hotel or a restaurant then when choosing a type of training.

Being better informed means being in a position to survey training provision. This was stressed in the report of the Advisory Group on Competitiveness which proposed the setting up of 'knowledge resource centres' to act as an interface between the supply of and demand for information on training.

It also implies an independent assessment of training, i.e. an assessment made outside the education system. This assessment should be simple, establish a ranking and make clear comparisons, making it possible to establish the real 
contribution to employability made by training. It is also important to evaluate how training reduces the segregation in the labour market by encouraging more women to enter traditionally male-dominated occupations. Such an assessment process would remove the first obstacle to guidance.

The second obstacle to guidance is the problem of knowing how occupations will develop and what skills will be required. Asking this question at the European level would make it possible to have a comparative outlook which is broader and which could contribute to finding a solution.

The third obstacle lies in attitudes. Significant progress has been made, but social origins continue to mark, indeed condition, choices made by individuals which can work against their social advancement.

ii) The second condition is broad
and open access serving
individual aptitudes and
needs.

Fulfilling this condition implies
mobility between educational
establishments. This mobility has
markedly increased in the Member
States, a trend which is to be
encouraged.

Mobility has also increased throughout Europe and the Community has made a significant contribution to this process, particularly through the ERASMUS programme. Yet mobility levels remain unsatisfactory.
There are two main obstacles to the occupational mobility of people, be they workers - employees, teachers, researchers, unemployed people - or those in training, particularly students.

First of all, there is the major issue of securing genuine recognition of knowledge within the EU. Mutual recognition of diplomas is guaranteed for the regulated professions and has been confirmed through Community case law. But recognition of diplomas still comes up against restrictions for other occupations. The diploma signifies academic recognition, but the component parts which make up the diploma are not recognised, except when it is encouraged by the Community through cooperation between higher education establishments and so through Community funding. An example is the cooperation between over 40 translation/interpreting schools within the Tradutech network, which has since 1986 provided mobility for teachers and students by applying the European Course Credit Transfer System (ECTS) as part of ERASMUS.

Validation of occupational achievements, outside the paper qualification, between one Member State and another is even more difficult to achieve.

Legal and administrative barriers are the second major obstacle to transnational mobility. Depending on the situation and the Member State concerned, these barriers stem from social protection provisions (particularly as regards pension schemes), right of residence (especially in the case of persons 
who are legally resident in a Member State but are nationals of a non-EU country) and fiscal regulations (e.g. those applying to study grants or research bursaries). The fact that national higher education study grants are not transferable from one country to another is an additional barrier to mobility.

The move towards the learning society means doing away with barriers to the physical mobility of people in Europe in an age when, due to the new communications technologies, instant non-physical mobility is a reality.

There must be access to training throughout life.

The conclusions of both the Essen and the Cannes European Councils stressed the need to develop continuing training, as have the authorities in the Member States and the social partners.

Yet there is no sign of much progress in recent years. On the contrary, the bite of the recession, the presence of surplus labour market and the arrival of overqualified young persons on the same labour market have done nothing to spur a training drive by the business sector, particularly for the benefit of the older and less-qualified employees. Inequalities in access to training between different types of companies and groups of employees persist. In particular, this works to the disadvantage of workers in SMEs and under- or unqualified workers. This also affects women, either because they are under-represented in senior management positions and in technology-intensive sectors, or because of the employment status of many of them (for example part-time workers). However, some progress has been made, for example "IDEALS", a project supported under the Community's 'Telematics applications' programme, has, in conjunction with SMEs and technical teaching establishments, made it possible to develop training for SMEs (data bases of course modules tailored to the requirements of the different SMEs involved), at the place of work or at local teaching centres.

The overall training effort remains too modest. The emergence of the information society and the resulting changes in the content and organisation of work nevertheless make it urgent to improve workers' access to training. They also make it necessary to enhance its content, which should not stop at mere adaptation to a new job.

- $\quad$ All the opportunities offered by the information society must be seized.

What is at stake must be seen from the point of view of both the education and the business sector. The facts are there. Competition from the USA is stiff generally in multimedia and in multimedia for education in particular. Europe's weakness does not lie in a lack of creativity. Far from it. But European inventors and industrialists are seriously hampered by the high degree of fragmentation of the market caused by the cultural and linguistic diversity of Europe. It is consequently difficult to make local, regional and national investment cost-effective, hence the case for encouraging the preparation of products which can be sold not only in Europe but throughout the world. 
Teachers must also be given the opportunity to adapt to new technologies and to their consequences. The penetration rate of educational multimedia at school is still too slow. There are several reasons for this. The quality of the products available today is not yet good enough to prompt teachers to use multimedia techniques. The development of multimedia educational software which the European Commission is supporting through the creation of the Task Force on educational multimedia software is, therefore, particularly important. In addition, teaching staff do not always have the right type and the right amount of hardware. Finally, teachers are not, in the main, sufficiently well-versed in the use of educational multimedia techniques.

The information society also raises another question. As stressed by the EU's Committee of the Regions in its opinion (September 1995) on "Education and training in the face of technical and social challenge: first thoughts" the question is how, "to promote equal access to education for men and women alike, and to ensure that disadvantaged groups (rural communities, the elderly, ethnic minorities and immigrants) do not become second-class citizens as regards access to the new technologies and opportunities for learning.".

The Commission believes that there remains too much inequality in the access to training and to the labour market and that the possibilities offered by the information society must be fully used to reduce them.
Information technology will certainly permit substantial growth in all forms of distance teaching. This was a point made by the European Parliament in its July 1993 resolution on open and distance learning, on the basis of the report by Mrs D. Pack.

The achievements of the Open University, which has for many years developed distance learning on a substantial scale, should also be mentioned in this context.

Lastly, specific career access pathways enabling marginal or excluded sectors of the population to find subsequently either training or a work-related activity still need to be developed. This White Paper considers this to be a priority. There has been a substantial effort in the Member States to set up specialised routes and arrangements for bringing marginalized groups back into the mainstream. The results, particularly in the problems of reintegrating young people, suggest that there is need for "second chance" arrangements, for which the European Union could provide some support, as proposed in the second part of this White Paper.

\section{b) Recognition of acquired skills}

In the learning society individuals must be able to have their basic, technical and occupational skills validated, how they were acquired. There are already instances of this: the driving licence, English (TEFL) and maths (Kangaroo test). A personal skills card providing a record of skills and knowledge accredited in this way should be available to all those who want one. 
This could be applied to certain fundamental areas of knowledge which can be easily broken down into different levels (languages, maths, management, informatics, law, economics, etc.). It could also be applied to technical areas of knowledge which are assessed in companies (accounting, financing, exporting, etc.) and even to occupational areas which cut across a number of different disciplines (sense of order, certain areas of decision-making, etc.). In this way, for instance, someone with no paper qualifications can approach a prospective employer, show that they have accredited drafting, language, word processing and spreadsheet skills, and thus attract interest in the range of skills they have put together, even though they do not have the piece of paper giving them the status of a qualified secretary. There are other examples, such as management and computing.

A number of skill accreditation and assessment systems developed for their own purposes by companies in Europe, could also be adopted for general use subject to validation by experts.

An accreditation system of this kind, on a voluntary basis, widely available in Europe and involving universities, chambers of commerce and specific business sectors, would complement the formal qualifications systems and would in no way be a replacement.

The introduction of new methods of validating skills, as proposed in the second part of this White Paper, would be a step towards the learning society.

\section{c) Positioning the individual within a supporting cooperative network}

While reliance on a single institution to build up employability is an increasingly unsatisfactory option, people cannot be left to fend for themselves either. The indications are that it is by being positioned in cooperative a network that people will be best served in educational terms.

i) \begin{tabular}{lr} 
Cooperation & between \\
\hline institutions and & others \\
\hline concerned. &
\end{tabular}

Adapting and improving
education and training systems has
to be strengthened through
partnerships: no single institution,
school or company can claim to be
able to develop the skills needed for
achieving employability.

In early childhood, it is cooperation between school and family which best secures the acquisition of basic knowledge. Special attention must be devoted in this connection to the role of the family, particularly in the disadvantaged areas. Families must be closely associated in the operation of "second chance" institutions and be provided with support programmes.

At a later stage, this cooperation takes place between education institutions and enterprises. In many Member States on-and-off-the-job training is being developed, particularly apprenticeship, which is still the most effective form of this cooperation. Apprenticeship should be encouraged at European level and apprenticeship pathways made 
possible between the Member States.

In the second part of this White Paper it is accordingly proposed to develop

\section{apprenticeship/traineeship at} European level.

Generally speaking, it is to be hoped that partnerships between companies and education establishments can be established.

Cooperation of this type is catching on, particularly through the contribution of Community action in the COMETT programme. Mention can be made of ECATA (European Consortium for Advanced Training in Aeronautics), a transnational project bringing together seven universities from several countries and eleven European manufacturers within a partnership to train young engineers, with the training being certified by a diploma. There is also Biomerit, involving some thirty-three partners universities, firms, particularly SMEs from seven European Union countries.

The challenge of cooperation between education establishments and enterprises is to accept enterprises as full partners in the training process. It is no longer possible to consider the company's role as solely that of recruiter of trained individuals or supplier of extra training. The enterprise is a major generator of knowledge and new know-how.

It should be noted that trends in training processes (particularly in the transversal areas: environment, health, consumption) is increasingly accompanied and sustained by a very broad partnership involving, for instance, local authorities, consumer associations and specialised bodies (tourism, energy, environment).

\section{ii) $\quad$ A network which is teaching- oriented and is itself a learning system.}

As stressed by Carnoy and Castells (in "Sustainable flexibility: a prospective study on work, family and society in the information age" of the School of Education, University of Stanford, Berkeley University, April 1995), this condition applies to cooperation within organisations, cooperation between networks of organisations and cooperation at local level.

\section{- $\quad$ Internal training networks}

In an enterprise it is acknowledged that working as a member of a team which has been given responsibility, makes it possible to improve the quality of production. Quality circles, job enrichment, plans bringing together workers, production and marketing managers, have all enabled working groups to learn and to teach, bringing benefits to everyone. On the basis of occupational experience, such cooperation has made it possible to transform automatic know-how into a capacity for autonomy, i.e. into a genuine form of knowledge.

This is becoming more widespread even outside quality circles. One example, concerns a leading European car manufacturer's plant in which a problem of blistering on car roofs was solved by having the workers themselves do the statistical surveys, monitoring and analysis of the problem (FORCE programme). 
This cooperation is beginning to bring about a radical change in the nature of vocational training in enterprises, which is increasingly taking place on the basis of a training plan which the workers themselves and their representatives have been involved in preparing. In the most progressive and most efficient companies, this training is organised less and less around the acquisition of skills for a specific task or even a clearly-defined job. Such specific type of training is now more generally used to complete the training of young people entering the company straight from school or university.

Teaching methods in teaching establishments should also move in the direction of learning how to cooperate.

There have already been some notable achievements. For instance, the 'European School Project' initiated by the Centre for Technical and Collaborative Innovation at the University of Amsterdam, involves 400 schools. It uses the "teletrip" principle, an educational project designed by teaching staff working together and covering information research, the exchange of results and problem solving. Several hundred "teletrips" have taken place in a number of different languages, involving thousands of students.

\section{- External cooperation networks}

Throughout Europe, there is a move towards local cooperation (in science and technology parks, urban multisite technology zones, etc.), based on the exchange of information and training between research institutes, companies and teaching establishments. In involving all the key interests, particularly national and local authorities, such local networks represent another factor promoting individual employability.

Similarly, the networks linking individuals and collective bodies involved in local development, particularly those active in community life, often enable jobs to be found, which, although they are of low added value, help to prevent the problem of exclusion. In general, these networks aim not only to find constructive employment for young people and others excluded from the labour market, but to teach them to communicate, to do something useful and to change their social environment. Their motives are altruistic, generally unrelated to paid employment but give them an opportunity to acquire the key skills in the learning society.

Regional and local cooperation is therefore of prime importance in enhancing employability. It enables the creation of jobs with high added value to be combined with the development of policies to help marginalised groups to integrate. It is also one of the main ways of generalising vocational training and strengthening cohesion in the European Union.

Local knowledge exchange networks are spreading across Europe, in France, Germany, Austria, Belgium, Spain, Switzerland, enabling people to share skills and train themselves by 'exchanging knowledge', everyone taking their turn to be first teacher, then pupil. There is a wide variety of areas which are conducive to exchange, ranging from informatics to languages and even chess games. 
Significantly, these networks are in general involved in eliminating illiteracy and providing support for school work. This has served as the platform for the development of an informatics-based method for managing skills, designed to develop group training. This method is currently being tried out by several enterprises.

\section{Directions for the future}

The crucial problem of employment in a permanently changing economy compels the education and training system to change. The design of appropriate education and training strategies to address work and employment issues is, therefore, a central preoccupation.

Everyone is convinced of the need for change, the proof being the demise of the major ideological disputes on the objectives of education.

The central question now is how to move towards greater flexibility in education and training systems, taking take account of the diversity of people's demands. Debate within the Union must now focus on this priority issue.

The diversity of current educational practice within the Member States shows that responses to this question are already emerging.

Major developments in the adaptation of education and training are taking place in the following three main areas: greater autonomy for those involved in training; awareness of the need to evaluate the effectiveness of education; and the realization that disadvantaged groups need special attention.

\section{A. The end of debate on educational principles}

Heated debates concerning the organization of education and training systems - including debates on content and training methods - have taken place over the last few years.

Most of these debates now appear to have come to an end.

\begin{abstract}
A broad knowledge base and training for employment are no longer two contradictory or separate things. There is increasing recognition for the importance of general knowledge in using vocational skills.
\end{abstract}

Bridges are being built between school and the business sector. These show that the ideological and cultural barriers which separated education and enterprise are breaking down, benefiting both. In line with the traditions in the Member States, this cooperation is reflected in initial and continuing training.

- $\quad$ The principle of equal rights in education is being applied increasingly in the context of equality of opportunity, including positive discrimination in favour of those at a disadvantage in order to prevent underachievement at school. 
- The dawning of the information society, which initially caused misgivings within the teaching profession, has now revealed new demand for education and training and has started to renew teaching approaches, while facilitating the development of contacts and links between teachers and institutions on a European scale.

\section{B. The central question:} towards greater flexibility

The current structure of education and training institution must change to meet the needs of different groups.

These institutions remain too rigid to educate and train citizens or workers for permanent employment. Even though some institutions or teachers are experimenting with new approaches, they remain too isolated.

There needs to be a commitment to greater flexibility to meet greater and more diverse demands.

How can this be achieved? An urgent debate on this issue is needed based on some key questions.

- How can the development of schooling and access to higher education for more people, be reconciled with maintaining quality in education?

- How can the purposes of education be adapted to the diversity of demands, whilst their remains some reluctance in education to differentiate between its clientele?
- How can the status of teachers and trainers be maintained and improved whilst motivating them to meet the manifold needs of the learning society?

- $\quad$ How can teachers and trainers be prepared for the development of the purposes of education and the consequent transformation of teaching methods and tools?

How can the conditions for lifelong learning be created, namely, the on-going access to the renewing of skills and the acquisition of new knowledge?

\section{Action in the Member States}

Significant developments are taking place throughout Europe. All education systems are seeking to improve quality, to develop training provision, to provide life-long learning, and to improve the use of financial resources.

\section{The search for quality}

In initial education, the focus is shifting back to acquiring and mastering basic skills, particularly the "three Rs" - reading, writing and arithmetic. There is also a general movement towards advanced learning of foreign languages. Member States are also seeking to familiarise young people with new information technologies.

Teachers and trainers are developing new innovative approaches both inside and outside the institutional education system. At school, this 
involves various methods e.g Decroly (Belgium), Steiner (Germany), Montessori (Italy), and Freinet (France). Innovatory methods are also emerging for adult education, e.g. the adult education schools or 'Outward Bound' courses as developed in the United Kingdom, offering exercises and approaches which transform the content of traditional continuing training by seeking to adapt behavioural patterns rather than abstract knowledge.

All these experiments show teachers and trainers possess genuine creativeness waiting to express itself. Teachers and trainers in the field are usually ahead of the education systems and it is among their ranks that the pioneers of the learning society are to be found.

At higher education levels, trends towards longer studies and wider access for a greater number, are clear signs of an overall increase in the quality of human capital. However, all higher education systems face the problem of tackling this sudden numerical increase, while maintaining the quality of their qualifications.

\section{The search for new types of qualifications}

All Member States consider the links between education and training as being of key significance. Some Member States are seeking to provide for the acquisition of basic skills within the education system placing an emphasis on trainee/apprenticeship schemes. Some have opted for twinning arrangements between schools and businesses. The main concern being both to place young people in a "work situation" while maintaining the quality of teaching. Other Member States prefer to delay the initial vocational training phase.

The involvement of businesses and the social partners in organising initial training and young people's transition to working life appears to be an established trend, notably in the form of on-and-off-the-job training (for instance in the "dual" system).

Some Member States are trying to develop "re-integration" or "guaranteed training" structures, which aim is to provide young jobmarket entrants lacking qualifications with another opportunity to acquire indispensable vocational and basic skills.

Several Member States are debating the processes of certification, validation and recognition of skills acquired, in particular those obtained in a work situation, as traditional processes are often too formal and rigid.

\section{The development of continuing training}

The concept of key skills is spreading throughout training. Occupations and qualifications are becoming more flexible. All Member States believe that the separation between education and vocational training is becoming less and less clear.

The widespread growth of social exclusion and the mid-term demographic outlook, have prompted most Member States develop their adult education, particularly at local level. 
In several Member States, training arrangements are emerging on the basis of a joint approach between the social partners, involving discussion, negotiation and even management of training issues. In view of the shared interests in, for instance, on-and-offthe-job training and arrangements combining working time and training, the collective agreement approach at different levels is becoming more noticeable in a number of Member States.

\section{New methods of funding and evaluation}

Some Member States are trying out new methods for funding education and training. These range from educational vouchers to co-funding of continuing training, where those involved themselves bear some of the cost (through tax allowances, subsidised loans or the introduction of a "training fund").

The search for new forms of funding for education and training is set in a context where, even though they occupy a major position in public spending, there has been a certain retrenchment over the past few years.

The debate now in progress in Member States on the public funds and resources to be devoted to education and training is being accompanied by an increased desire for greater transparency of the systems and, above all, for evaluation of the cost effectiveness of public expenditure in this field. The problem is to obtain reliable reference benchmarks and, above all, data on private funding (households, companies, etc.). At a time when the discussion on transfers of funds is picking up speed in all Member States, those in positions of responsibility are showing increasing interest in improving cost-benefit appraisal methods.

\section{New Developments}

In the light of these changes and experiences, new developments can be seen clearly to be going in three main directions.

The first concerns the increase in autonomy for those involved in education and training.

It is by giving greater autonomy to those responsible for education and a clear understanding of its purpose that education and training systems can adapt better to meet modern needs.

There is the question of whether to give greater autonomy to schools. Experience has shown that the most decentralised systems are also the most flexible, the quickest to adapt and hence have the greatest propensity to develop new forms of social partnership.

In the field of continuing training, this necessary autonomy must be part of the process of negotiation between the social partners at various levels (company, sectoral, regional, intersectoral), the essential aim being to ensure that all workers, particularly employees in the SMEs, have access to training.

The second new development is evaluation, which is needed to justify the essential increase in funding. 
Evaluation is equally relevant in ascertaining how effectively education and training cater for the needs of target groups as well as in the search for ways of improving achievement at school, integration into working life and vocational retraining. Education can also help to tailor more effectively both initial and continuing vocational training to the requirements of the employment market, characterised as it is at present by a high rate of unemployment and a shortage of labour in certain sectors and certain trades.

Evaluation can enable continuing training to be considered as an investment made by enterprises and by workers. In addition, money spent on in-company retraining or apprenticeship, for example, constitutes an asset for the company alongside its other fixed assets e.g. research equipment. Such investment should therefore be treated in the same way for tax purposes without prejudicing the free movement of workers. This is proposed in the second part of this White Paper.

Evaluation can also help to publicise and disseminate experience and best practice, which is why in the second part of this White Paper setting up an observation system to monitor innovatory vocational training practices is proposed.

Finally, the third new development concerns the attention being given to disadvantaged groups.

It is becoming increasingly clear that those not integrated into society should receive special attention, so as to give them basic skills, and cultivate fundamental values. As the European Parliament stressed in its initial resolution of March 1993, based on Mrs Dührkop-Dührkop's report on the schooling of immigrant children, school plays a vital role in social integration.

Positive discrimination in favour of those at a social disadvantage is essential, particularly in the problem suburbs and inner-city areas. Otherwise, the risk is that the social rift widens even further. These areas must benefit from increasing public aid and the concentration of institutional means to implement policies based on local administration and the social fabric, in particular local associations. They should be given the most highly qualified teachers - not inexperienced or temporary staff - using new information technology. Support at school must be strengthened in close conjunction with families.

Moving towards the learning society is a twofold challenge.

The first challenge is economic. The $\mathrm{EU}$, as the world's leading exporter, has quite logically opted to open up to the international economy. This means it has to continually strengthen its economic competitiveness as the route to achieving the "...sustainable and noninflationary growth respecting the environment..." and the "high level of employment and of social protection..." set out in Art. 2 of the Treaty establishing the European Community. 
As stressed in the Commission's White Paper "Growth, competitiveness and employment" its human resources constitute the EU's main economic asset. More recently, the Commission Communication "An industrial competitiveness policy for the European Union" clearly set out the terms of the issues at stake: "The European Union's greatest asset for boosting its industrial competitiveness is its capacity to generate and use knowledge, with the aid of the great potential of its labour force and the social consensus laying the foundation for harnessing it."

Europe must invest in education to raise the general level of skills of employees and the working population, through basic education and by fostering the acquisition of new knowledge throughout life. This intangible investment must make it possible to meet the challenge posed by developments in the labour market i.e. the mismatch between qualifications sought and qualifications available, demographic change, the growth of service sector activities and changes in the organisation and content of work.

All this is accompanied on the social front by an urgent need to avert a rift in society. Social exclusion has become widespread in Europe in recent years and there is no need to dwell on the consequences of this situation.

Clearly, a special effort has to be made for the most vulnerable sections of the population, particularly in the urban areas hardest hit by unemployment. This effort depends on initial and continuing training, as well as measures to give young people leaving school with no qualifications a second chance.

Naturally, everything starts at school, which is where the learning society has its roots. If this White Paper has placed so much emphasis on the role of individuals as the main protagonist in that society, through his selfreliance and the thirst for knowledge which will enable them to take charge of their own future, it is only to highlight the role of school in this process. School has to adapt, but nevertheless remains the irreplaceable instrument of everyone's personal development and social integration. Much is asked of it because it has such so much to offer. 
-29 - 


\section{PART TWO: BUILDING THE LEARNING SOCIETY}

\section{Action guideline proposals}

The learning society will not come about overnight. It cannot come about by declaration. It has to emerge from an ongoing process. This White Paper does not purport to present a package of measures. The Commission neither has nor proposes any miracle solution. The White Paper merely offers a basis for thorough consideration and outlines some courses of action.

The scale of the changes in progress nonetheless requires an all-round effort if Europe wishes to make the urgent need to invest more and more efficiently in knowledge something more than a mere slogan.

What is now needed is a different approach for three reasons:

giving priority to quality in education and training has become vital to the EU's competitiveness and to the preservation of its social model; indeed Europe's very identity over the next millennium depends on this;

- the demand for education and training is continually increasing; on the supply side, the emergence of the information society is providing a new potential;

- social exclusion has reached such intolerable proportions that the rift between those who have knowledge and those who do not, has to be narrowed.

Efforts are being made in all Member States to improve the general level of skills, starting with an effort to give back to school its crucial role in society and to strengthen its role in providing equality of opportunity, in particular between women and men. The European Union has done its utmost within its limited budgetary and legal framework. No one can question the success of programmes like ERASMUS, COMETT and LINGUA which have served hundreds of thousands of Europeans well and which have helped to bring about a radical change of attitude, particularly among the young, for whom Europe has become a reality.

The guiding principles for these programmes when they were launched in the 1980s have been carried through to the LEONARDO and SOCRATES programmes. In addition, the reforms to the Structural Funds - particularly Objective 4 - has made it possible to develop Community initiatives in the form of specific programmes such as EMPLOYMENT and ADAPT, which have boosted education and training efforts. In addition, the 4th framework research programme for the first time makes financial provision for research into education and training.

The point is not to make a clean sweep of local, national and European achievement, and still less to advocate reform of the education systems, but rather instead to attempt to put those involved - trainers, companies, public authorities - 
on the same wavelength as regards new courses of action which could quickly be turned into practical measures.

It is for this reason that this White Paper will to launch in 1996, the European Year of Lifelong Learning, a debate which, in pursuing common objectives, will conform to the principle of subsidiarity and make it easier to distinguish between:

action to be carried out at local and national level;

action to be carried out at European level;

cooperation and support between the EU and its Member States.

The Commission intends to present the conclusions of this debate and will propose guidelines for further action.

Based on these respective competencies, the principle of subsidiarity is an essential part of this forthcoming debate for the following reasons:

* $\quad$ Firstly, the authors of the Treaty state explicitly in Articles 126 and 127 that Community action in education and training is to complement and support action taken at national level, as responsibility for the content and organisation of their education and vocational training systems rests with Member States.

* Secondly, the principle of subsidiarity whereby decisions should be taken at the most appropriate level must be a major feature of any action taken in education and training and is a major principle of the Treaty.

* More generally, this principle is particularly appropriate, as the highest political level, thus the furthest away from the area of application, should only act when individuals, families, and political authorities at all other levels cannot. As is shown in the analysis carried out in the first part of this White Paper, the move to the learning society must be centred on the individual. The Commission is, moreover, fully aware that in several Member States responsibility for action lies with the regional or other decentralised authorities.

Let us not forget, however, that to a greater extent than before, promoting the European dimension in education and training has become a necessity for efficiency in the face of internationalisation and to avoid the risk of a watered-down European society. If it is to preserve its diversity, its wealth of traditions and structures, Europe has to become - and increasingly so as successive enlargements come about - a focal point of action through the essential cooperation in these fields between the EU and its Member States.

As far as procedures are concerned, the Commission hopes that appropriate fora can be established in 1996 to discuss fully all the issues arising from the establishment of the learning society. One such forum could, for instance, be a 
"Jumbo" Council of Ministers bringing together not only the Ministers of education but also those responsible for social affairs and industry.

The Commission notes with interest that there is a shift in the government structures of a number of Member States to bring together the ministries of education with those of research and training, a move which has taken place within the Commission itself.

As far as the funding of future action is concerned, the Commission obviously has no intention of interfering with internal decisions of the Member States, while at the same time hoping that priority continues to be given to investment in education and training.

As far as the Community is concerned, the Commission is also aware that in view of the financial perspective, additional funding has to be ruled out for the time being. It accordingly stresses that the measures proposed generate little cost although this does not detract from their innovatory nature - and will be financed by reallocating funds within existing programmes. With reference in particular to SOCRATES and LEONARDO, a plan of action will be submitted in 1996 around the objectives set out in the second part of this White Paper.

Against this background, the second part of this White Paper presents ideas for action to facilitate cooperation between all those concerned or to complement their activities, leaving each to exercise their full responsibilities:

- Member States are responsible for shaping and developing the structure, organisation and content of their educational and vocational training systems. They therefore have a crucial role to play in bringing about the learning society;

- $\quad$ educational and training establishments must be strengthened and actively participate in setting up cooperation networks involving others concerned;

- $\quad$ enterprises must have an increasing role in training and must help to disseminate any new skills developed from their experience;

individuals must also be able to enjoy permanent access to a whole range of better targeted and more clearly identifiable education and training provision, which complements general knowledge and can be acquired outside formal systems.

In order to promote these ideas and to implement practical action, the Commission has identified five general objectives which are to:

- $\quad$ encourage the acquisition of new knowledge

- $\quad$ bring schools and the business sector closer together

- $\quad$ combat exclusion 


\section{- $\quad$ develop proficiency in three Community languages}

- treat capital investment and investment in training on an equal basis.

For each of these objectives this document puts forward guidelines, suggestions and measures which the Community could undertake to complement and support national action. It formulates for each general objective a significant and experimental project (see box in the text) to point the way forward.

This project could initially be started up under the SOCRATES and LEONARDO programmes and subsequently be fully implemented under the structural initiatives, particularly "EMPLOYMENT" (YOUTHSTART) and "ADAPT". As regards European-level support, proposals are grouped by theme rather than area (education, training). The legal reference basis for each of these proposals will be defined if and when a proposal for an appropriate instrument is submitted, depending on the reactions from the Member States, the European Parliament and other parties interested in this White Paper. 


\section{First general objective}

\section{"ENCOURAGE THE ACQUISITION OF NEW KNOWLEDGE"}

Enhancing knowledge - by which we mean individuals' general level of knowledge - ought to be the top priority. To achieve this a large number of measures - analyzed in the first section of this document - are needed, and Member States have the main responsibility for putting these in place.

One general and universally acknowledged principle must be observed: the advent of the learning society involves encouraging the acquisition of new knowledge.

A multitude of incentives to learn must be provided.

The improvement of information about existing training will be facilitated by setting up creation, in the countries "Knowledge Resource Centres" as proposed in the Ciampi report.

Harnessing the knowledge acquired by individuals throughout their life must be based on opening up new methods of recognising skills, over and above paper qualifications and initial training, starting at national and local level.

Support for mobility also plays a part in encouraging the enhancement of knowledge. Geographical mobility broadens the individual's horizon, stimulates intellectual agility and raises the general level of learning. It can only reinforce the ability to learn, which is so necessary to develop.
Finally, education and training must draw on the new communication technologies and harness their full potential. In the long run every class should have the necessary equipment allowing young people access to the world of computers. This means, in particular, that Europe must adopt new high-quality teaching instruments adapted to its educational and cultural traditions.

This White Paper therefore proposes launching the following support actions at European level:

\section{A. Recognition of skills}

All European countries are attempting to identify "key skills" and the best ways of acquiring, assessing and certifying them. It is proposed to set up a European system to compare and disseminate such definitions, methods and practices. What does this entail?

The underlying idea (involving cooperation between all the European players concerned) is as follows:

first, to pinpoint a number of
well-defined areas of
knowledge of a general or
more specialised nature
(mathematics, informatics,
languages, accountancy,
finance, management, etc.);
second, devise validation
systems for each of them;
third, introduce new, more
flexible, ways of
acknowledging skills.

In complementing formal qualification systems, this approach would provide 
individuals with greater independence in putting together their own qualifications. It will awaken a new thirst for education in those not wishing or unable to learn in a conventional teaching setting.

If we manage to set up this knowledge accreditation system - on a voluntary basis - at European level, we will have taken a huge stride towards the learning society.

A project will be launched concerning the "personal skills cards". This document should allow individuals to have their knowledge and know-how recognised as and when they are acquired. It is important to discover, through studies and pilot projects, what type of data is relevant and to consider how individuals could use such a card. The aim is not to devise a uniform card and impose it on Europe, but to contribute to the development of such tools, so as to progressively arrive at joint standards, including standards that cut across a number of occupations.

A European accreditation system covering technical and vocational skills will be set up (see box) based on a cooperative venture involving higher education establishments, businesses, vocational sectors, local chambers of commerce and the social partners.

Finally, support will be given to concluding a whole range of agreements - at company, branch and regional levels etc. incorporating the principle of the personal skills card.

\section{B. Mobility}

Student mobility will be made easier. In line with the Resolution of the European Parliament and the Conclusions of the Council of Ministers (1993), any students obtaining a grant in their own country must be able, if they wish, to use it in any higher education establishment in another Member State prepared to accept them. The Commission will submit a proposal to this effect.

New "masters" level courses will be devised, in cooperation with several higher education institutions through pooling human and material resources; these will lead to mutually recognized qualifications responding to the skill needs of the single market.

Mutual academic and vocational recognition will be developed by the generation of the system of "credit" transfers (European Credit Transfer System - ECTS) and the application of equivalent methods to vocational training. The aim is to obtain mutual recognition of training modules, giving preference to agreements between education and training establishments and between economic sectors.

The obstacles (administrative, legal and those connected with social protection) acting as a brake on exchanges of students, trainees, teachers and researchers must be removed; the Commission will work out specific proposals on the basis of guidelines in a Green Paper on these matters included in its work programme. 


\section{Multimedia educational software}

As part of the European Year of Lifelong Learning (1996), and in conjunction with the "multimedia educational software" Task Force, software development will be supported through:

launching joint calls for proposals for the relevant Community programmes (SOCRATES, LEONARDO, ESPRIT, TELEMATIQUE, MEDIA II, INFO 2000);

setting up a mechanism to enhance and brand educational software and European products for use in education and training in order to facilitate their dissemination. 


\section{Opening up new avenues for validating skills}

Aims

- Generate education and training demand from young people or adults unable or not wishing to enter either a formal system leading to paper qualifications nor to undergo initial vocational training.

- $\quad$ Render it possible for each individual to have partial skills recognised under a flexible and permanent system (to be used by each individual as desired) for validating knowledge units.

- Identify, assess and reach a common agreement on such knowledge units.

- Encourage individuals to assemble their qualifications themselves, notably through accreditation of such knowledge units.

Methods

- Support European cooperation in pinpointing ways of breaking down the broad discipline fields into basic units.

- $\quad$ Set up European networks of vocational training centres, businesses and vocational sectors making it possible to identify the technical and vocational knowledge in greatest demand, the content of essential "key skills" and ways to obtaining them.

- Determine the best ways of accrediting knowledge (widely used evaluation software packages, evaluators, tests, etc.).

- Unify the projects undertaken along these lines within the overall framework of a European accreditation system which will award a European label.

- Devise formats for the personal skills card. 


\section{Second general objective}

\section{"BRING SCHOOLS AND THE BUSINESS SECTOR CLOSER TOGETHER"}

Schools and businesses mutually complement one another as places of learning and they should be brought closer together. This happened in a number of European countries a long time ago. In others it happened late and gradually, or not at all and the separation of the worlds of learning and production continues.

Building or reinforcing bridges between schools and businesses can do nothing but good, for both sides, and helps underpin equal employment opportunities. With respect to the world of learning in the widest sense, stretching from primary to higher education, training courses must be better matched to employment opportunities. As for the business sector, it stands gain workers possessing technical qualifications, basic skills and a general cultural upbringing who are able to think for themselves and are receptive to change. This approach increases the job prospects for all trainees.

Therefore, bringing schools and the business sector closer together is a priority in which the social partners must play their role and which involves three conditions.

Firstly, education must be opened up to the world of work. Without reducing the point of education solely to the purpose of employment, an understanding of the world of work, a knowledge of enterprises and an insight into the changes which mark production processes are some of the basics which schooling must take into account.

Secondly, companies must be involved in the training drive, not only as regards workers but also young people and adults. Training cannot be seen purely as a way of supplying skilled labour to firms; enterprises bear a responsibility, i.e. that of giving a chance - often in the form of a job - to those who were failed by the traditional education systems. Companies need to grasp this more clearly. Some have made substantial efforts to reskill their staff, thus enabling them to cope with technological innovation, while others have not, throwing onto the streets workers who clearly could be retrained.

Thirdly, cooperation must be developed between schools and firms.

Reinforcing the links between schools and the business sector must be based primarily on apprenticeship/trainee schemes. This approach is suitable for all qualification levels and is catching on in higher education, following initiatives by engineering or business schools. For example, after incorporating this method into its own training approaches, a major French business school, the ESSEC, is now helping to promote it at European level in cooperation with other European higher education establishments such as the London Business School, the Università Bocconi in Milan, or the University of Mannheim.

Apprenticeship/trainee schemes are able to provide young people with 
both the required knowledge plus experience of life and work within companies. By providing them with their first contact with the world of work, it places them at a considerable advantage for entering the job market. Promotion of apprenticeship/trainee schemes at European level will provide added value for both young people and companies.

Closer links between the worlds of education and work should also make it possible to promote and revamp, both initial and continuing vocational training. This covers all employees. One thing cannot be denied: Europe needs skilled production workers if it is to remain a major industrial power; it must uphold its great tradition of skilled workmanship while adapting it to new production conditions such as the mastering of new technologies, the importance of maintenance and backup activities, worker empowerment for independent working, team working, involvement in top-quality research, etc. More generally, Europe needs a type of vocational training no longer broken down into small specific areas and compartments, but which allows everyone to understand, and thus to master, the job they do and even to improve themselves in their job. This means, for instance:

allowing technicians to
become engineers by supplementing their training with more general instruction in organisation, management and line authority, etc.;

allowing engineers - as well as workers - to understand the process as a whole, from production to sales and final use of the product (installation, maintenance).

As the Commission's Communication on "The Craft Sector and Small Enterprises: keys to growth and employment in Europe" (Com(95)502 final) shows, the service sector, the craft sector and small enterprises are key to job creation. The emergence of new on-and-off-the-job training, matching new job profiles arising in the service sector needs to be encouraged and training on how to set up in business supported.

Innovation in the vocational training sector must also be stimulated: innovation in training will engender innovation in the wider world.

Against this background the White Paper proposes the following measures:

\section{A. Apprenticeship/trainee schemes}

Apprenticeship/trainee schemes in Europe will be based and developed along the lines of the ERASMUS model (see box). Support funds will be made available by redeploying current programmes, particularly LEONARDO.

The aim is to improve opportunities for young people returning to some extent, throughout the Union and in the most diverse of occupations, to the "journeyman" spirit, which contributed so much to the quality of European products and has demonstrated how important mobility is in acquiring knowledge and knowhow.

A major effort should be undertaken to set up the necessary work- 
shadowing/mentoring arrangements and provide apprentices with someone to tutor them. This is a vital prerequisite for developing this approach, but is sometimes difficult to achieve.

Finally, a European apprentice/trainee charter needs to be drawn up in the light of the Green Paper on obstacles to the transnational mobility of people in training.

Parallel to this, more widespread opportunities for undertaking periods of in-company training at European level are to be provided, through a European agreement involving business confederations.

\section{B. Vocational training}

Training for the new occupations in the service sector is to be encouraged, emphasising the need for it to be multidisciplinary. For example, training for jobs in the tourism and environmental protection fields, which are now fully coming into their own, needs to be promoted.

Support will also be provided for training service-sector engineers and technicians. Production, installation, maintenance/servicing, repair, advice to users - services are everywhere. The emergence of new consumer goods, particularly in the computer and communications technology fields, is increasing considerably the demand for services which manufacturers' or distributors' aftersales service departments are not always able to satisfy. In areas such as these, service training cannot be separated from production. Therefore, the aim must be to train engineers and technicians more specifically geared to service activities and consumer needs, through interdisciplinary courses provided, in part, within a company and leading to a diploma or certificate for service-sector engineers or technicians.

Training in how to set up in business is to be fostered. The best ways of encouraging people, young ones in particular, to start up a small business will be examined with the Member States and social partners. The Green Paper on Innovation will, however, show that a lot still needs to be done to simplify the bureaucracy required for enterprise creation.

A European observation system to survey innovatory vocational training practices will be set up within the Commission to facilitate the exchange and dissemination of good practice and innovative projects within the European Union.

In the same vein, arrangements will be put in place for forecasting needs in terms of skills, qualifications and new occupations. 


\section{Example $\mathrm{N}^{\circ 2}$}

\section{Developing apprenticeship/trainee schemes in Europe}

Aims

- Develop all forms of apprenticeship/trainee schemes (on-and-off-the-job training courses, etc.) at all levels across Europe by facilitating mobility between various European apprenticeship/trainee centres for meaningful periods.

- Revive the traditional "journeyman" system to provide in-training vocational and educational experience within various cultural and company environments.

- $\quad$ Promote new forms of tutoring and mentoring arrangements, taking account of the European dimension.

Methods

- Set up and consolidate networks of apprenticeship/trainee centres covering various European countries.

- $\quad$ Foster apprentice/trainee mobility along the lines of ERASMUS.

- Establish a European apprentice/trainee charter as part of the follow-up to the Green Paper on obstacles to transnational mobility of trainees. 
III. Third general objective

\section{"COMBAT EXCLUSION"}

The development of our economies and the constraints of competitiveness have led to several categories of the population being left by the wayside (young people without qualifications, older workers, longterm unemployed, women re-entering the job market). The analysis in the first part of the White Paper shows that these groups are even more vulnerable since access to knowledge is crucial to fitting into society and finding employment.

In order to curb this process of marginalisation, Member States have launched a series of measures, based mainly on increasing the number of training or back-to-work schemes and various measures aimed at reintegrating those facing the greatest difficulty and centring on action by local groupings. One can, thus, see the use of enterprise initiatives and workshops and other methods of re-integration through vocational activities, clearly structured and leading to a qualification. Funding such measures weighs very heavily on the public purse and the Community has made a major contribution via the Structural Funds.

To supplement all the above measures this White Paper emphasizes the need to promote two types of pilot scheme to point the way forward, of a type already underway in some Member States to combat exclusion and develop a sense of belonging, namely "second chance" schools and voluntary service for young people.

\section{A. Second chance schools}

The basic idea is simple: provide youngsters excluded from the education system, or about to be, with the best training and best support arrangements to give them self-confidence.

As school is indeed a "first chance" giving every individual the opportunity to integrate into society, it has to be said that, unfortunately, this is no longer the case for the most disadvantaged, who quite often do not have a suitable family and social setting to enable them to benefit from the general education provided at school. Young people excluded from the school system can now be counted in tens of thousands in the major conurbations. Without qualifications, they have little hope of finding a job and thus of integrating into society.

Pilot projects undertaken in Member States clearly show that a second chance must not mean "ghettoschools". To an increasing degree schools located in problem areas are offering a second chance, or new centres of learning are being set up, equipped with additional resources depending on where they are located.

The task of such schools is to improve access to knowledge through employing the best teachers, if necessary paying a higher than normal salary, through customising the pace of teaching, providing new incentives, arranging in-company training, using multimedia and running 
classes containing fewer pupils (see box).

Another aim must be to turn the school - in problem areas where social and family values are generally collapsing - into an educational meeting place for the community where teachers are present outside school hours.

Second chance schemes are intended for the entire school population of a deprived area, without differentiating between those able to attend a traditional type of school and those not able to do so, so as to avoid any form of segregation.

It should be noted that many projects aimed at providing a "second chance" have long been in existence. In the USA, 500 "accelerated schools" (see annex 3) have been set up in urban areas and use consolidated and accelerated teaching methods. During the G7 information society meeting held in Brussels last February, the Americans explained that young people dropping out of the traditional training system had found their way back to learning when provided with computers and the best teachers. They had quickly taken to the idea of interactivity, in contrast to the passivity they had shown in a conventional teaching setting. Such schools should, as far as possible, combine pupils whose schooling has been interrupted and pupils capable of being taught by traditional methods.

In Israel, even before it became a State, a novel education system was developed as part of the "societies for the young" set up in village communities, making it possible to receive and integrate child refugees from Europe whose family ties had been severed. This educational approach - known as Alyat Hanoar (see annex 4) - has successfully integrated young people from Morocco, Russia, Ethiopia, etc. Since its inception this system has educated and integrated into Israeli society more than 300,000 youngsters, with a drop-out rate much lower than the national average.

In a totally different context, but also to tackle a crisis situation, it is not surprising that local authorities in Europe, with the support of other groups, are reverting to the idea, initially started in Europe between the wars, of offering a second chance through schools. In problem suburban areas, pilot second chance projects are being undertaken, involving greater resources (in terms of teachers and infrastructure) and drawing inspiration from the earlier models as the first step towards reintegration. This is the case in the Netherlands, Spain and France, where measures are being taken at local level. Of the many European-level projects, one under the COMENIUS programme involves five major European cities (Antwerp, Bologna, Bradford, Marseilles and Turin), which have set up an educational partnership aimed at socially integrating the children of immigrant families through successful school careers.

Some governments have given significant financial support to second chance projects in big-city suburbs and have positive discrimination measures setting up specially designated local environments of the 'free zone' type. 
The Commission intends - notably under the SOCRATES and LEONARDO programmes - to provide support for such second chance schemes via the co-funding of a certain number of pilot projects, the networking of projects under way and the dissemination of pedagogical approaches (see box). Through this it aims to begin a debate to discover whether the time is ripe to encourage the establishment of second chance schools on a wider scale.

\section{B. European voluntary service}

Voluntary service initiatives exist in a number of Member States. Without substituting for military service, it provides young people with a chance to engage in an activity serving the common good, either in their own country or in a developing one.

The European Union has also made a modest contribution - on an experimental basis - through the "YOUTH FOR EUROPE" programme. Parallel to this, the YOUTHSTART programme contains provision - under the heading of vocational training - for funding measures supporting initiatives to integrate youngsters lacking qualifications.

All these activities, although interesting, are limited in scope. Furthermore, they have not led to genuinely multilateral projects. Since no rules exist governing such voluntary service, they are fraught with many obstacles as regards free movement, taxation and social security.

The European Parliament, several Member States and some voluntary sector organizations have recently made an increasing number of requests for the adoption of practical measures which aim to promote voluntary service at European level to complement actions at national level, in accordance with the principle of subsidiarity.

This is the spirit behind the ad hoc committee "A Citizen's Europe" (Adonnino report, 1985) and the European Parliament Resolutions of 22 September and 5 October 1995.

The idea of creating a "European voluntary service for humanitarian aid", has also been taken up the intergovernmental conference study group.

To promote the development of European voluntary service, the Commission will:

$$
\begin{aligned}
& \text { launch a support measure } \\
& \text { within the framework of the } \\
& \text { existing "YOUTH FOR } \\
& \text { EUROPE" programme } \\
& \text { (already adopted by the } \\
& \text { Council and Parliament) for a } \\
& \text { significant number of young } \\
& \text { volunteers to undertake a } \\
& \text { variety of public service tasks } \\
& \text { outside their own country. This } \\
& \text { voluntary service could be } \\
& \text { carried out inside the } \\
& \text { Community, in particular in } \\
& \text { problem neighbourhoods and } \\
& \text { outside the Community in } \\
& \text { multinational teams working in } \\
& \text { developing countries; }
\end{aligned}
$$

examine the possibility of establishing a legal and financial framework on the basis of Articles 126 and 127 of the Treaty establishing the European Community, to facilitate the development and coordination of national and Community projects in the field 
of European voluntary service,

in particular by eliminating

certain obstacles to the free

movement of young

volunteers. 


\section{Example $\mathrm{N}^{\circ} 3$}

\section{Providing a second chance through school}

Aims

- Reintegrate young people without paper qualifications and living in deprived areas in major conurbations through schemes offering a second chance of obtaining an education, by refashioning schools already located in such areas or setting up new centres of learning.

- $\quad$ Provide pupils with highly competent teachers, deploying especially qualified staff, paid as well as those in the most reputable establishments.

- Develop, among young people, motivation, the ability to learn how to learn, basic knowledge and social skills.

- Reduce class-sizes.

Methods

- Assemble additional European funds to support national or regional funding for setting up pathways to integration.

Introduce measures involving consultation and partnership with the economic players so as to augment opportunities for integration into employment when training pathways have been completed.

- $\quad$ Arrange, at the start of any training pathway, personal sponsorship by a local SME or major company, if possible backed up by a promise of employment if the relevant qualifications or skills recognition are obtained.

Adopt teaching approaches customised in terms of pace and drawing on the new educational technologies.

Network second chance schemes and spread pedagogical methods.

Closely associate families with the school's activities and approach.

Make full use (in association with companies) of information and multimedia technologies.

Develop, on an intensive basis, sports and cultural activities. 


\section{Fourth general objective}

\section{"PROFICIENCY IN THREE COMMUNITY LANGUAGES"}

\begin{abstract}
Proficiency in several Community languages has become a precondition if citizens of the European Union are to benefit from the occupational and personal opportunities open to them in the border-free Single Market. This language proficiency must be backed up by the ability to adapt to working and living environments characterised by different cultures.
\end{abstract}

Languages are also the key to knowing other people. Proficiency in languages helps to build up the feeling of being European with all its cultural wealth and diversity and of understanding between the citizens of Europe.

Learning languages also has another important effect: experience shows that when undertaken from a very early age, it is an important factor in doing well at school. Contact with another language is not only compatible with becoming proficient in one's mother tongue, it also makes it easier. It opens the mind, stimulates intellectual agility and, of course, expands people's cultural horizon. Multilingualism is part and parcel of both European identity/citizenship and the learning society.

The European Union, for its part, is contributing to the development of language learning as part of LINGUA, now integrated in the SOCRATES and LEONARDO programmes.
It is no longer possible to reserve proficiency in foreign languages for an elite or for those who acquire it on account of their geographical mobility. In line with the resolution of the Council of Education Ministers of 31 March 1995, it is becoming necessary for everyone, irrespective of training and education routes chosen, to be able to acquire and keep up their ability to communicate in at least two Community languages in addition to their mother tongue. The Commission regrets the fact that the importance of this commitment was reduced, the Member States limiting its effect by using the words "if possible".

In order to make for proficiency in three Community languages, it is desirable for foreign language learning to start at pre-school level. It seems essential for such teaching to be placed on a systematic footing in primary education, with the learning of a second Community foreign language starting in secondary school. It could even be argued that secondary school pupils should study certain subjects in the first foreign language learned, as is the case in the European schools. Upon completing initial training everyone should be proficient in two Community foreign languages.

Vocational training - initial and continuing - must place great stress on language learning. This is of dual significance for working life because it constitutes a major element in a person's general cultural development and is an advantage when it comes to obtaining a job, either inside one's home country or when taking up the option of mobility available within the Union. 
All this presupposes the availability of top-quality education drawing on modern materials, equipment and methods customised to meet the needs of the diverse groups involved.

In keeping with this, the White Paper proposes the following support measures at European level:

Community support for the introduction of assessment systems (including elaboration of quality indicators) and quality guarantee systems, covering the methods and materials used to teach Community languages.

Definition of a "European quality label" and its award to schools meeting certain criteria regarding promotion of Community language learning (see box).

Support for exchanges of language-teaching materials suitable for different groups (adults, the low-qualified, young children, etc.).

Encouraging the early teaching of Community languages, notably through the exchange of teaching materials and experience in this area. 


\section{Example $\mathrm{N}^{\circ} 4$}

\section{"European quality label"}

Aims

- $\quad$ Promote the learning of at least two Community foreign languages by all young people.

- Encourage innovatory language-teaching methods.

- Spread the daily use of European foreign languages in schools of all levels.

- Foster awareness of Community languages and cultures, and their early learning.

Methods

- Mobilising schools to provide learning of at least one Community foreign language as early as primary school.

- $\quad$ Define a "European quality label" quality label which would be awarded according to the following criteria:

- $\quad$ genuine use by all pupils of one Community foreign language at primary school and of two at secondary school.

- $\quad$ involvement of teaching staff from other EU Member States.

- $\quad$ use of methods promoting self-learning of languages.

- creation of an organisation for contact between young people from different Member States (including via information technologies).

Promotion of this label will make it possible to assemble additional funding from the Member States (including local authorities).

Networking establishments having obtained this label.

Systematically encouraging mobility to allow teachers to teach their mother tongue in schools in another country, as permitted by Community law and the ensuing changes made in civil service structures. 


\section{Fifth general objective}

\section{"TREAT CAPITAL INVESTMENT AND INVESTMENT IN TRAINING ON AN EQUAL BASIS"}

The White Paper acknowledges that investment in skills is a prime factor in competitiveness and employability. In order to put this guideline for action into practice two items have to be analyzed in order to produce proposals for action:

investment inputs in human capital;

$\begin{array}{llr}\text { accounting } & \text { and } & \text { fiscal } \\ \text { approaches } & \text { to } & \text { training } \\ \text { expenditure. } & & \end{array}$

On the first, it should be noted that expenditure on education and training is severely affected by the economic cycle and fluctuations in the levels of activity. This is particularly true in the case of companies which, as recession bites, cut back substantially on their expenditure in this area. As regards public expenditure, the context of austerity and reduction of public sector deficits calls for greater attention to maintaining public investment in education and training.

As regards the accounting and fiscal approach, labour is not considered as an asset. It is an operating cost and is included as such in the company balance sheet in the form of remuneration and taxes. The approach to be explored is how to consider know-how and skills acquired by employees during the course of their duties as adding value to the company, so that part of the expenditure on training and salaries during the training period can be considered as depreciable intangible fixed assets and transferred accordingly on the balance sheet.

A priority task is to consolidate the funding levels agreed in connection with education and training (which implies measuring them), to develop direct and indirect incentives promoting investment in human resources and to improve accounting and expenditure monitoring arrangements.

It is especially desirable, as the Commission has already proposed in its Communication on "An industrial competitiveness policy for the European Union" (COM 94/319 final), to introduce arrangements whereby companies which have made a special effort in training can enter some of this investment in their balance sheet as part of their intangible assets. In addition, 'training fund' schemes should be devised for those who wish to update their knowledge or to re-embark upon training after having earlier interrupted their studies.

Development of the information society already involves putting in place a growing number of new goods and services which will play an increasingly important role in enhancing knowledge. The fiscal systems in many Member States already have some provisions allowing individuals to offset against tax certain types of expenditure on their training. The time has come to ask whether such systems should be reviewed and rapidly expanded to take account of technological progress and to allow citizens to devote the highest possible investment to ongoing improvement of their knowledge. 
The White Paper proposes the following support measures at European level:

- $\quad$ measurement of investment in education and training on the one hand; and

- promotion of investment in human resources on the other.

General management charts (tableau de bord) will be drawn up for the EU showing public and private investment in education and training.

A survey of the arrangements for aiding and encouraging investment in education and training in Europe will be carried out, the aim being to spread knowledge and understanding about them.

On the basis of a study covering the different fiscal and accounting approaches to companies' and individuals' training expenditure, consultation will be initiated with Member States on promoting investment in human resources as a fixed asset (see box). 


\section{Example $\mathrm{N}^{\circ} 5$}

\section{Promoting investment in human resources}

Aims

- $\quad$ Promote the perception of training as an investment and not as operating expenditure.

- $\quad$ Encourage people to invest in their own training along "training fund" lines.

- $\quad$ Foster cooperation between national systems from the point of view of the accounting and fiscal approach to training expenditure.

- $\quad$ Bring the fiscal and accounting approaches to intangible investment closer together, particularly as regards research and training expenditure.

Methods

- Identify the different arrangements for fiscal and accounting handling of training expenditure by companies and individuals.

- $\quad$ Assess the financial implications for Member States and companies.

- $\quad$ Build up Community expertise in ways of handling training expenditure as an investment for companies and individuals.

- Joint examination with the Member States and the social partners of the legal and administrative arrangements for treating training expenditure by companies as investments. 


\section{GENERAL CONCLUSION}

The world is going through a period of transition and profound change and the signs are that in Europe, as elsewhere, a new age is about to dawn which is more variable and unpredictable than those which went before.

There is no doubt that this new age - one of internationalisation of trade, of the information society, of scientific and technical upheaval - brings uncertainties and concerns, primarily because it is difficult to see the direction of the future.

These uncertainties and concerns are without doubt stronger in Europe than elsewhere. European civilisation has a long history and is very complex. It is today divided between a deep thirst for research and knowledge, the legacy of a tradition which made Europe the first to bring about a technical and industrial revolution and thus change the world, and a deep-seated call for stability and collective security. This is a perfectly understandable aspiration for a continent so long torn apart by wars and divided by political and social conflicts. Unfortunately, it is also one which can engender a reactionary reflex to change.

Yet this age of change is a historical opportunity for Europe, because such periods in which one society gives birth to the next are the only ones conducive to radical reform without violent change. The increase in trade across the world, scientific discoveries, new technologies, in fact open up new potential for development and progress.

An eminent European historian, co-director of the "Annales" and well-placed to compare this period of change with those that preceded it, particularly the transition from the Middle Ages to the Renaissance, said ${ }^{1}$ :

"The Europe of the Middle Ages and post-medieval times had to face up to the Byzantine world, the Arab world and the Ottoman Empire. The struggle today is fortunately set in a more pacific context. Nevertheless, the existence of protagonists in history gigantic by their size or by their economic strength, or indeed both, means Europe has to achieve a comparable scale if it is to exist, progress and retain its identity. Facing up to America, Japan and soon China, Europe must have the economic, demographic and political mass capable of securing its independence.

Fortunately, Europe has the weight of its civilisation and its common heritage behind it. Over 25 centuries European civilisation has, in successive stages, been creative; and even today, as one slogan goes, Europe's main raw material is unquestionably its grey matter.

It is in the European dimension that a forward-looking society can be built, capable at the same time of helping to change the nature of things globally and of maintaining full awareness of itself.

Jacques LE GOFF - La vieille Europe et la nôtre - 1994 - Paris, Editions du Seuil. 
This White Paper contends that it is by building up the learning society of Europe as quickly as possible, that this objective can be attained. This move entails radical change. All too often education and training systems map out career paths on a once-and-for-all basis. There is too much inflexibility, too much compartmentalisation of education and training systems and not enough bridges, or enough possibilities to let in new patterns of lifelong learning.

Education and training provide the reference points needed to affirm collective identity, while at the same time permitting further advances in science and technology. The independence they give, if shared by everyone, strengthens the sense of cohesion and anchors the feeling of belonging. Europe's cultural diversity, its long existence and the mobility between different cultures are invaluable assets for adapting to the new world on the horizon.

Being European is to have the advantage of a cultural background of unparalleled variety and depth. It should also mean having full access to knowledge and skill. The purpose of the White Paper is to make it possible to exploit these possibilities further; the recommendations it contains cannot claim to provide an exhaustive response to the question.

Their aim is much more modest, namely to help, in conjunction with the education and training policies of the Member States, to put Europe on the road to the learning society. They are also intended to pave the way for a broader debate in the years ahead. Lastly, they can help to show that the future of Europe and its place in the world depend on its ability to give as much room for the personal fulfilment of its citizens, men and women alike, as it has up to now given to economic and monetary issues. It is in this way that Europe will prove that it is not simply a free trade area, but an organised political entity, and a way of coming successfully to terms with, rather than being subject to, internationalisation. 
Annex 1

\section{Some data and figures}

Note:

1. The data and figures given below are taken from a number of documents produced by the European Commission or the OECD. As is the case with all statistics, all the more so when they are of a comparative nature, they should be treated with caution, especially since most of them refer to the 1991/92 year.

2. The data and figures on vocational training relate mainly to continuing training (partly because in several Member States initial training comes under the national education system, for example in France, and is generally called technical training). What is more, to the extent that continuing training is mainly a matter for companies (and economic sectors), it is difficult to obtain precise and overall figures.

\section{EDUCATION}

$\Rightarrow \quad$ In 1993 there were nearly 117 million under-25s in the Union's Member States, i.e. $32 \%$ of the population. Ireland has most young people in relative terms (43\%), i.e. one and a half times more than Germany, which has the lowest percentage. Since 1973 the percentage of under-25s in the population has decreased in all Member States. Several countries with the highest percentage of under-25s (Spain, Finland, Netherlands, Portugal), experienced the greatest decrease. It should be noted, too, that the percentage of under-25s in the population is very unevenly distributed: from over $35 \%$ in southern Portugal, southern Italy, northern half of France or in Ireland for example, to less than $29 \%$ in the northern regions of Italy and the new Länder in the Federal Republic of Germany.

$\Rightarrow \quad$ During the 1991/92 academic year there were 67 million pupils and students in the European Union, i.e. almost one-fifth of the total population (based on Europe of the 12). Almost $60 \%$ of the under-25s were enrolled in an educational establishment. If one takes into account the pupils enrolled in pre-school education, then almost 77 million under-25s were in education in 1992 throughout what was Europe of the 12, i.e. near on $70 \%$ of that population group.

- In 1991/92, the European Union (12 Member States) had over 22 million young people in primary education, i.e. over a third of the population in education. 
- Nearly 35 million pupils were enrolled in secondary education establishments in the European Union in 1991/92, i.e. $52 \%$ of all youngsters in education. The corresponding percentages vary only slightly between the countries: from $44 \%$ in Portugal to almost $60 \%$ in Germany. Throughout the Union (particularly in Germany, Italy, Netherlands, Austria and Sweden) there are more young people in technical secondary education than in the general academic sector (almost $79 \%$ in Germany).

- Nearly 10 million youngsters attended a higher education establishment in 1991/92, i.e. $14 \%$ of all youngsters in education: this percentage was highest in Denmark and lowest in Portugal. It should be noted (still with reference to 1991/92) that 5\% of the students were non-nationals (here again with large variations between Member States $-10.4 \%$ in Belgium and $1.4 \%$ in Greece).

$\Rightarrow \quad$ Not all young people necessarily leave school with a qualification: the ratio between the number of certificates awarded and the number of 18 year-olds was 0.81 in the European Union in respect of secondary education; the ratio between the number of certificates awarded and the number of 23 year-olds in the European Union for that same year (1990/91) was 0.23 . In both cases the situation varied greatly from one Member State to another.

$\Rightarrow \quad$ There were over 4 million teachers in the European Union in 1991/92 (not counting higher education).

$\Rightarrow \quad$ Most educational establishments throughout the European Union are within the public domain: over $70 \%$ of establishments come directly under the public sector. Italy has the largest percentage of totally independent private establishments (i.e. private and receiving less than $50 \%$ of their resources from the public sector).

$\Rightarrow \quad$ Over $\mathbf{2 0} \%$ of under-25s not in education were unemployed in March 1995, this rate varying from $6.5 \%$ in Luxembourg to over $45 \%$ in Spain. In all the Union countries, apart from Germany, unemployment among young people is significantly higher than the labour force as a whole.

$\Rightarrow \quad$ As a general rule (except for Greece and Italy), there is a direct relationship between level of education and unemployment rate: the higher the former, the lower the latter among young people: in Belgium, Denmark, Germany, Spain, France, Ireland, Italy, Finland, Sweden and the United Kingdom this rate amounted to or exceeded $15 \%$ for young people not continuing past the first level of secondary education, whereas in the same Member States it was below 10\% for those who had completed some form of higher education. 
$\Rightarrow \quad$ Expenditure on education accounts for a very large proportion of public spending. Finland earmarks the largest percentage of GNP to education (1992 figure), i.e. near on 8\%. For the countries where data were available, this figure varies between $7.9 \%$ and $5 \%$ (Germany, Netherlands). Except for the Netherlands, where the proportion of private establishments is fairly high (3.3\% of GNP), almost all spending on education goes to establishments in the public sector. There is not necessarily a direct link between the percentage of GNP allocated to education and expenditure per pupil relative to GNP per capita.

$\Rightarrow \quad$ At present, more than 500000 students are enrolled in higher-level distance education in Europe, i.e. some $7 \%$ of the population in higher education.

\section{VOCATIONAL EDUCATION AND TRAINING}

$\Rightarrow \quad 60 \%$ of young people were engaged in vocational training at upper secondary level (63\% of males and $58 \%$ of females) in 1991/92. The United Kingdom is the only country where there are more females in vocational training $(59 \%)$ than males $(52 \%)$.

$\Rightarrow \quad$ Public expenditure on vocational training programmes was $0.5 \%$ of GDP in 1993 as compared to $0.25 \%$ in 1985 . It is estimated that employers spend approximately $1.5 \%$ of the total wages and salary bill on vocational training.

$\Rightarrow \quad$ It is estimated that every year in the EU at least $20 \%$ of the economically active population is engaged in continuing vocational training/ education of various kinds for two weeks on average. According to a survey carried out in 1993 in 12 Member States, some 5\% of male employees and $6 \%$ of female employees aged over 25 had undergone vocational training in the four weeks prior to the survey.

$\Rightarrow \quad$ The private sector is playing a larger role than ever as a training provider. The number of training practitioners in the European Union is put at over 60000 .

$\Rightarrow \quad$ Although there are over $\mathbf{3} 000$ establishments of higher learning in the European Union, their role in continuing training is modest. In terms of persons involved, higher education establishments in France account for $5 \%$, the corresponding figure in Germany is 2 to $3 \%$, whereas in Scandinavia and the United Kingdom it is over $10 \%$.

$\Rightarrow \quad$ Participation in continuing vocational training is linked to level of education. The figures, for Member States where the information was available, indicate that people having undergone upper secondary 
education participate more in continuing training throughout their working life than those who left the system after lower secondary education. 


\section{Annex 2}

Examples of Community programmes in the field of education and training

\section{Examples of mobility}

\section{ERASMUS (students)}

Council Decision: 1987

Numbers concerned:1987-88: 3000 students who received grants 1995-96: $\quad 170000$ students who received grants

COMETT II (university-enterprise cooperation and traineeships in industry for students)

Council Decision:

Numbers concerned: $\quad$ 1990:

1994:

1988
1990: 4400 students in transnational traineeships

8700 students in transnational traineeships

$75 \%$ of companies participating in Comett projects were SMEs

PETRA II (young people in initial training and young workers)

Council Decision:

1991

Numbers concerned: $\quad$ 1992-94: 23566 young people in initial VT 13053 young workers

FORCE (continuing training in Europe)

Council Decision: 1990

Numbers concerned: $\quad 5000$ European partnerships, roughly 3000 of which being companies or consortia (inc. $70 \%$ SMEs) and 900 European training partnerships involving the social partners in 720 projects 


\section{Examples of projects within the Socrates programme}

- Higher Education Diploma in Administration and Management (Hedam). This was the fruit of academic cooperation. The course lasts for three years, $20 \%$ of the time being spent learning two languages. 300 students are currently working for the qualification. There are 22 partner institutions.

- $\quad$ Distance learning project put forward by the European Federation for the Education of the Children of Occupational Travellers (Efecot). This brings together 40 national associations and groups responsible for the education of children whose parents are in itinerant jobs (bargees, fairground entertainers, circus artistes, etc.). The project is also aimed at parents.

- $\quad$ Euroling computerised teaching material for elementary and intermediate courses in Italian, Spanish and Dutch. Can be used independently or in groups. The project involves eight European universities.

- Polyphonia (European music network - ERASMUS): 12 musicology faculties and European academies have formed a network for cooperation to encourage student and teacher mobility (joint courses and intensive programmes, joint examination boards). This network has given rise to a chamber orchestra and a brass ensemble.

- Tradutech (European network of translation/interpreting schools Erasmus): over 40 such European schools have since 1986 been cooperating on of student and teacher mobility. A technical back-up instrument for translation, Tradutech is one of the fruits of this cooperation. All the partners use the ECTS (European course credit transfer system). The learning of the European languages less widely used and taught has been stepped up and a project which is unique in Europe in the field of interpreter training in sign language is currently being developed.

- Diecec (European network of cooperation between towns in the area of intercultural education - COMENIUS): in order to head off deskilling and unemployment, five major European cities (Marseilles, Antwerp, Bradford, Bologna and Turin) have created an education partnership to promote the integration of the children of immigrant persons by improving the rate of success at school.

- $\quad$ Adele (Apprentissage de la dimension européenne en langues étrangères LINGUA): by setting up transnational working parties involving four countries (France, Portugal, Spain and Greece), multimedia training modules are prepared jointly in order to introduce the European dimension into education, backed up by teaching method sheets for foreign language teachers. 
- $\quad$ Meithal (Initial teacher training and the European dimension - COMENIUS): this network (whose name means "working together" in Gaelic) has since 1990 being bringing together for a one-month period around a specific theme ("art in Europe" in 1994) teachers and future teachers from 12 establishments from eight European Union countries, the aim being to foster exchange and reflection on the European dimension in the initial training of teachers.

\section{Examples of projects within the Leonardo programme}

Quality system (FORCE): a consortium of Spanish, Irish and Portuguese companies has organised a training programme tailored to the needs of European SMEs as regards implementing quality programmes, seeking to incorporate quality into the management strategy of companies and as a human resource management instrument. This project has also contributed to the dissemination of ISO 9000 quality standards. The product is available in four languages on CD Rom.

- International programme for placement of young people in initial training in the metal industries-(PETRA): organisation in Denmark as part of an exercise managed by the joint committee for the metal industries of a basic training programme which contains a compulsory placement period abroad in all types of training. Similar developments have followed through regulations in the Netherlands, Italy and Spain.

- $\quad$ Euskal-Herria (COMETT): University-Enterprise Association for Training (UETP) involves ten companies, seven universities and eighteen trade federations from the Basque country and other European regions and has endeavoured to develop training and retraining courses to improve the quality of the labour market for workers needing retraining or workers who are unemployed.

- $\quad$ Preparation and validation of a new workshop occupational profile the 'expert technician' (FORCE): this project targets highly qualified employees; the partnership involves European car manufacturers, dealers and training centres in several countries and has led to the development of two multimedia educational software packages relating to noise control techniques in cars and the airbag.

- Biomerit (European network in the field of biotechnology training COMETT): this involves some 33 partners from 7 European Union countries. Biomerit has in three years organised nearly 15 training seminars involving around 900 participants. One of the main achievements of Biomerit is to have familiarised both students and researchers with work in European networks and companies in order to introduce biotechnological innovations in farms and SMEs. 
- $\quad$ Setting up business abroad (PETRA): business schools in Denmark, Luxembourg, the Netherlands and Portugal work as a partnership on the simulation of setting up transnational businesses as part of an initial training network. Projects for setting up businesses abroad are pursued in each training centre. These projects have a specific aim and are scrutinised by local assessment boards (chambers of commerce, companies) at a "business fair".

- $\quad$ Ecata (COMETT): a transnational training project in advanced aeronautics technology. Seven universities from several countries and eleven European manufacturers cooperate within this partnership targeting young engineers. The training is certified by a diploma and over 2000 hours of training have been provided since 1990 .

\section{Examples of projects under the telematic project programme}

- Learning through exploration and discovery: two consortia of companies and educational institutions have set up two training schemes one for medical students and the other for technical secondary students based on intense use of simulated practical work. The students are given integrated educational support providing them with guidance and explanations on request. This approach stresses inductive reasoning and should engender knowledge which is deeper and more easily transferable (COAST and SERVIVE projects).

- Inter-university cooperation to promote new educational services: it is not enough to provide access to vast knowledge resources, they must be structured to match the target populations' needs, be attractive to students and motivate them. This concept - of a "hot house" for knowledge defined and fed by a consortium of universities (ARIADNE project) - is currently being validated in a group of companies to check its economic and social pertinence. A second consortium of universities is trying out distribution of services via hybrid networks combining cable TV, public telecommunications and research networks (ELECTRA project).

- Training at SMEs: a consortium made up of technical education institutions and SMEs is helping to develop a database covering training course modules. Training service providers adapt standard modules to their customers' specific needs. Users have access to the training resources either via a company work station or a local training centre (IDEALS project).

- Training at home: this type of distance training is the more usual one, since advances in telematics allow top-quality pedagogical support to be provided, coupled with improved trainer-trainee interaction and a media-rich environment. The DOMITEL project is experimenting with cable TV while TOPILOT has opted for a solution customised for migrant workers based on mobile data communications technology. 
- Specialised training networks: a growing number of training courses in leading-edge technologies are not available at university, either because there is not enough local demand to economically justify creation of an advanced course, or because the research in question is principally conducted by companies. Europe is the most suitable level at which to organise such types of training. Two consortia are assessing new training approaches adapted to these new needs. The first is run by a network of microelectronic research laboratories (MODEM) and the second by a network of national meteorological institutes (EUROMET). 


\section{Annex 3}

\section{The educational world of Alyat Hanoar}

Alyat Hanoar is an institution in Israel specialising in education of youngsters exposed to especially acute problems during adolescence because of specific family, social or cultural problems, which prevent them from growing into responsible adults.

Initially launched in Germany in 1932 to save the children of Jewish families suffering from discriminatory measures, mainly in the employment field, this undertaking aimed at transferring groups of such young people to Palestine and providing them with education and training as part of "communities of independent young people" in certain kibbutzim.

For nearly 30 years this organisation has continued, in particular, to educate adolescent immigrants, more particularly traumatised child survivors of the concentration camps and then adolescent emigrants, without parents, from the Maghreb and Iran. From the early 60s on Alyat Hanoar became increasingly involved with adolescents from what is known as "Second Israel", i.e. the vast numbers of people - from Morocco in particular - who never integrated properly. In 1985 it again steered a new course, when it was given the task of organising the adaptation, education and integration of all youngsters among the 50000 Ethiopian Jews transferred to Israel under particularly traumatic and testing circumstances.

The keystone in this educational venture to achieve the psychological, cultural and social reintegration of such individuals is the "village of the young", or more precisely a network of such villages. Such villages consist not only of adolescent students (aged from 14 to 18) but also of teachers, support staff ("mothers" or "fathers", educators, instructors, psychology counsellors, social workers, etc.) and technical/administrative personnel, many of whom also live on campus, often with their families.

Social matters within this set-up are decided by a number of bodies composed of students (student boards, various committees, households and so on). Adult staff regularly attend meetings with the village director where they are provided with guidance on setting a good example for the adolescents, being someone with whom the latter can identify, from whom they can receive support and with whom they can interact.

The education provided within such villages has three main aims, namely. to:

1. Foster individuals' independence and consolidate and develop their personality through interaction among the students themselves and between students and staff. 
2. Expand upon the educational curricula laid down by the Ministry of Education, by taking a wider perspective and developing whatever talents students possess - in the field of sport, art, music, etc. - by means of courses, workshops, visits and other complementary activities.

3. Foster the individual students' sense of responsibility towards their group as such and society as a whole by delegating jobs to each of them (taking turns to work in the refectory, library, sports/playing fields, tidying up living quarters, etc.) or specific tasks (giving extra teaching lessons, accompanying a student to the community clinic, hospital, etc.).

The most remarkable feature of all, without any doubt, is that this educational system operates with hardly any recourse to the usual sanctions imposed by teachers or parents. Social pressure takes over this role in the "village of the young" and is much more effective.

The results achieved by this model are impressive. Not only has it turned out a large number of leading figures, but the proportion of drop-outs from this type of education is much lower than the national average (3\% as against $10 \%)$ despite the fact that a good many of such adolescents had dropped out several times before. The flexibility of this approach and its ability to overcome major cultural differences and deep-seated prejudices have also been borne out by the impressive results obtained, in less than ten years, in integrating young immigrants from Ethiopia.

Since it was set up Alyat Hanoar has educated over 300000 youngsters. Nowadays, the sixty or so villages it operates contain over 17000 adolescents, i.e. one third of the young people studying in a similar framework, or $10 \%$ to $12 \%$ of students in the age group in question.

The average annual cost per student in such villages is relatively modest at FF 35000 to FF 45 000, teaching costs included. 


\section{Annex 4}

\section{The experience of "Accelerated schools" in the USA}

A success story in the USA, "accelerated schools" constitute one of the best solutions Americans have found to the crisis faced by their education system, confronted with under-achievement by near-on one third of primary and secondary pupils.

Such under-achievers, or "pupils at risk", are usually two years behind the others; over half of them leave school without any paper qualifications; most of them are from deprived and poor areas and belong to ethnic minorities not speaking English; many of them also come from single-parent families.

These accelerated schools are based on the conviction that all pupils in the same age group are capable of reaching the same level of academic achievement by the time they are of school-leaving age. This means that under-achievers have to be made to work at an accelerated pace as compared to better-off pupils, which is done by providing schools of excellence for the former.

The concept underlying these schools is that the teaching provided for "gifted" children is also suitable for all children. This means not viewing under-achievers as slow on the uptake and incapable of learning within the usual time frames, but - on the contrary - setting them ambitious objectives to be achieved within firmly fixed periods.

Every pupil, each parent, every teacher must be convinced that failure is not inevitable. Those involved are called on to work together, in cooperation with teaching staff, as a responsible community which has taken full possession of all rights and powers. After drawing up a common vision of what the school should be like, this school community sets out to build an accelerated school, firmly resolved to respond, on its own, to any problems as and when they arise.

Such a community needs to be founded on the generally under-used talents everyone has. The process of transforming the school changes attitudes and creates a new culture.

The process takes about five months to come to fruition, necessitating many hours of meetings and consultation between the teaching staff, parents and pupils.

Schools pursuing this path must not be left with the feeling that they are out on their own. They must receive support within a network of schools adopting the same approach. In the USA they have the support of teams at universities, Stanford University in particular.

Several hundred such projects have been successfully undertaken in the USA and form the object of studies and publications encouraging their continuation. 